\title{
Idealismo e realismo na teoria política e no pensamento brasileiro: \\ três modelos de história intelectual
}

Idealism and realism in political theory and in Brazilian thought: three models of intellectual history

\section{Introdução}

As principais interpretações do pensamento político brasileiro apresentam duas características particularmente salientes. A primeira delas reside na alta relevância conferida à identificação das mentalidades, famílias, tradições ou linhagens de sua cultura política. Assim, em Instituições políticas brasileiras (1949) Oliveira Vianna se referia às diferentes "mentalidades" da elite brasileira, cujas "metodologias" eram expressivas de diferentes "atitudes espirituais" perante a realidade política (VIANNA, 1974). Guerreiro Ramos voltaria ao assunto em A ideologia da ordem (1961): "No domínio da vida intelectual, há famílias. Isto é, grupos cujos integrantes são marcados sutil ou ostensivamente por um ar de família. Existe uma morfologia do espírito ou da inteligência" (RAMOS, 1961, p. 141). Em A práxis liberal no Brasil (1978), Wanderley Guilherme dos Santos aludiria às tradições intelectuais formadas por grupos políticos, atores e autores, cujo conhecimento era necessário para

\footnotetext{
Professor do Programa de Pós-Graduação em Ciência Política do Instituto de Estudos Sociais e Políticos da Universidade do Estado do Rio de Janeiro (IESP-UERJ), Rio de Janeiro, RJ, Brasil. Email: $<$ Clynch3@hotmail.com>

2 Pesquisador da Fundação Casa de Rui Barbosa (FCRB), Rio de Janeiro, RJ, Brasil

3 Professor da Universidade Veiga de Almeida (UVA), Rio de Janeiro, RJ, Brasil
} 
compreender tanto "a ação política, enquanto ideias traduzidas em comportamentos, quanto as ideias políticas, como guias estratégicos para a ação" (SANTOS, 2017, p. 166). Em Linhagens do pensamento político brasileiro (2005), Gildo Marçal Brandão igualmente sustentaria a "existência de famílias intelectuais que, a meu juízo e contra a aparência imediata das coisas, estruturam historicamente o pensamento político e, por essa via, a luta ideológica e política no Brasil” (BRANDÃO, 2007, p. 15). Bolívar Lamounier também se reportaria mais recentemente, em Tribunos, profetas e sacerdotes (2014), à existência de diferentes famílias ideológicas na vida brasileira, a partir das quais os intelectuais influenciavam "a evolução do sistema político" ao longo da história (LAMOUNIER, 2014, p. 14).

A segunda característica saliente dessas interpretações reside na tendência a aglutinar as referidas tradições em dois polos básicos: um, designado negativamente como idealista; o outro, positivamente, como realista. Por "idealismo" e "realismo" designo, aqui, mais do que o emprego literal dessas palavras, a crença nutrida por seus autores de que haveria algumas linhagens intelectuais mais capazes de enxergar a realidade como ela efetivamente seria ("realistas"), e outras, que o fariam de modo mais precário ou distorcido (“idealistas"). Em 1922, Oliveira Vianna já denunciava as elites políticas brasileiras por se orientarem conforme um idealismo utópico, que ignorava "as condições reais e orgânicas das sociedades que pretendem reger e dirigir". Contra esse cosmopolitismo alienante, o autor recomendava outro tipo de idealismo, o orgânico, alimentado da "realidade, que só se apoia na experiência, que só se orienta pela observação do povo e do meio" (VIANNA, 1922, p. 14-17). Por sua vez, Guerreiro Ramos classificaria, em 1955, os intelectuais brasileiros, distinguindo os hipercorretos dos pragmáticos-críticos. Os primeiros tenderiam a "atribuir ideais e teorias importadas eficácia direta na configuração de comportamentos sociais, assim negligenciando os seus condicionamentos contextuais”. Já os segundos tenderiam "mais a se servir das ideias e teorias importadas do que a admitir a sua exemplaridade abstrata" (RAMOS, 1983, p. 533). As três interpretações seguintes, formuladas já no contexto da 
ciência política institucionalizada, reiteraram essa tendência de aglutinar as tradições intelectuais em dois diferentes polos. Não haveria problema, se estivessem de acordo sobre quais seriam idealistas ou realistas. Não é isso, porém, o que acontece. O polo identificado como realista para Wanderley Guilherme é aquele por ele denominado autoritário instrumental; para Bolívar Lamounier, está identificado, ao contrário, com a linhagem chamada liberal; ao passo que, para Gildo Marçal, a perspectiva que abre as portas para a realidade é a marxista de matriz comunista. Daí a polêmica que acompanha todas essas interpretações, que, partindo sempre de Oliveira Vianna, dialogam entre si de modo crítico, quando não ácido ${ }^{4}$.

No intuito de compreender as razões do desacordo dessas interpretações e de sua tendência em aglutinar as tradições intelectuais em polos opostos, o presente artigo remonta ao quadro mais amplo da história do pensamento político. Em primeiro lugar, porque o pensamento brasileiro não é determinado somente por suas próprias tradições. Foi a partir de sua articulação com o movimento do mundo que nossos politólogos, desde o século 19, hauriram os seus modelos de história intelectual e estabeleceram seus critérios de distinção. Em segundo, é preciso remontar à história intelectual, porque a dicotomia idealismo e realismo parece entranhada na forma de estruturar a disciplina de teoria política. Edward Carr já consagrava, em 1939, a tese de que a moderna ciência política ("realista") teria surgido depois da Primeira Guerra Mundial, como reação a um paradigma oitocentista pautado por uma abordagem normativa e ingênua ("idealista"). Chegara o tempo em que "os pesquisadores pedirão auxílio à análise, e o estudo, emergindo do seu período infantil e utópico, estabelecerá o seu direito de ser visto como ciência” (CARR, 2001, p. 8). Também Raymond Aron denunciaria, na década de 1960, os analistas da Belle Époque por seu "idealismo jurídico", que superestimava o papel do direito na tomada de decisões ou estratégias (ARON, 2002, p. 706). Revisitar

4 Não é o caso de reapresentar aqui cada uma dessas interpretações de modo minucioso, eis que já foram objeto de artigos à parte, subscrevendo-se aqui as suas conclusões (LYNCH, 2013; LYNCH; CASSIMIRO, 2018; LYNCH; CHALOUB, 2021). 
a teoria política da primeira metade do século 20 parece assim um caminho especialmente útil para compreender o que seriam idealismo e realismo e explorar as alegadas diferenças entre um paradigma "idealista" de ciência política, próprio do século 19, e outro, "realista", próprio do seguinte. Na sequência, seria possível examinar como esse paradigma alegadamente novo teria dado origem a três modelos ideológicos de história intelectual, cada qual orientado por diferentes critérios acerca do que fosse a realidade política.

A hipótese ora apresentada é a de que a dualidade entre idealistas e realistas, empregada para distinguir as tradições do pensamento brasileiro, decorreria de uma antiga disputa da própria teoria política entre diferentes concepções acerca da realidade política e suas relações com a dimensão ética da vida social. A discórdia envolve questões relativas às características da natureza humana se "boa" ou "má" - e ao papel auxiliar do conhecimento histórico na sua compreensão - relativa à sua perfectibilidade ou imutabilidade. $\mathrm{O}$ debate parece ter sido filtrado por pelo menos três paradigmas sucessivos de ciência política. O primeiro, renascentista/seiscentista, já opunha o "idealismo" identificado com a ética católica dos escolásticos ao "realismo" dos teóricos da razão de Estado. O segundo, iluministal oitocentista, opunha o "idealismo" identificado com o progresso moral da humanidade ao "realismo" associado com a ordem e a autoridade, concebidos como forças metafísicas em eterna luta ao longo da história. Já o paradigma moderno/novecentista partiu de uma reação "materialista" contra a metafísica na segunda metade do século 19, passando pela reivindicação de neutralidade axiológica na análise do fenômeno político. Ela culminou com a proposta de uma ciência política compreensiva, desvinculada de uma filiação ingênua aos valores graças a 
procedimentos metodologicamente controlados ${ }^{5}$. Entretanto, diante da recusa de setores à direita e à esquerda, mas também de muitos liberais, em admitirem a possibilidade de uma cisão entre política e valores, a dicotomia realismo versus idealismo produziu três modelos de história intelectual ideologicamente distintos: o liberal, o nacionalista e o marxista. Esses três modelos ajudaram Wanderley Guilherme, Bolívar Lamounier e Gildo Marçal a organizar as suas próprias interpretações sobre as tradições intelectuais do pensamento político brasileiro, condicionando de modo visível a escolha do método científico, cada qual com suas preferências ideológicas subjacentes ${ }^{6}$.

Do ponto de vista metodológico, a pesquisa aqui desenvolvida tentou, por meio de um procedimento genético inspirado pela história dos conceitos de Reinhart Koselleck, rastrear as principais referências bibliográficas daquelas três interpretações, capazes de fornecer indicações das perspectivas por eles indicadas como "idealistas" e "realistas"7. Esse procedimento "rastreador" foi repetido de modo sucessivo e retrospectivo na literatura referenciada, a fim de

5 A análise algo sumária que se fará aqui dos "clássicos", especialmente dos mais icônicos (como Marx e Weber), não pode fazer justiça à sua complexidade em espaço tão exíguo. Por outro lado, em um estudo preocupado em identificar as referências intelectuais e ideológicas mais remotas dos intérpretes do pensamento brasileiro, é menos importante a suposta "verdadeira" exegese desses autores, em abstrato, do que a apresentação de seus argumentos gerais, especialmente na forma como foram lidos na primeira metade do século XX.

6 As interpretações de Wanderley Guilherme, Bolívar Lamounier e Gildo Marçal foram preferidas às de outros, com base em dois critérios. O primeiro, de caráter formal, exigia aderência à área de Ciência Política e aos seus métodos de pesquisa no campo teórico e excluiu colegas que militam nos campos da Sociologia, da História, da Filosofia e da Literatura. O segundo critério, substantivo, privilegiou politólogos cuja contribuição teórica tivesse sido abrangente e influente para o desenvolvimento da área. A combinação dos dois critérios levou a investigação a preferir Gildo Marçal Brandão ao sociólogo Luiz Werneck Vianna, um conhecido "intérprete do Brasil", para representar aqui o veio marxista; e a Wanderley Guilherme dos Santos a José Murilo de Carvalho, para ilustrar o veio "nacionalista". O próprio Murilo já reconheceu ser tributário da visão de Wanderley nesse assunto (CARVALHO, 2015, p. 118-120).

7 A história dos conceitos de Koselleck exige situar os conflitos do passado em suas respectivas fronteiras conceituais, relacionando-os com as transformações das estruturas políticas, econômicas e sociais. Embora ligados a uma palavra, os conceitos são sempre mais do que elas e não possuem conteúdos estáveis. Daí que as histórias dos conceitos sejam aquelas de suas diferentes recepções no tempo e no espaço (JASMIN; FERES JR., 2006, p. 25). O fato de não ser possível aqui aplicar rigorosamente os preceitos dessa metodologia não significa que o artigo não tenha-se balizado por ela o tanto quanto possível, para evitar excessos de anacronismos e pensar os processos de recepção intelectual. 
reconstituir, pelas vinculações de obra a obra, os fios que ligariam cada interpretação a um modelo específico de história intelectual. Cada um deles teria sido elaborado pela adaptação, à direita e à esquerda, de um paradigma alegadamente "realista" de ciência política surgido depois da Primeira Guerra Mundial na Alemanha, depois recepcionado na França, na Grã-Bretanha e nos Estados Unidos. A investigação cessa por volta de 1970, quando já estava formada a constelação intelectual que orientaria nossos três intérpretes em suas pesquisas sobre o pensamento político brasileiro. A primeira, de Wanderley Guilherme, seria elaborada na confluência de autores "nacionalistas", como Hans Morgenthau, com a tradição nacionalista brasileira, lida à esquerda por Guerreiro Ramos, ambas críticas de um liberalismo percebido como alienado, pois cosmopolita (LYNCH, 2013). A segunda, de Bolívar Lamounier, seria produzida à luz de autores "liberais", como Juan Linz, em crítica à tradição nacionalista, percebida como autoritária (LYNCH; CASSIMIRO, 2018). Já Gildo Marçal questionaria as interpretações precedentes como conservadoras à luz de autores "marxistas", como Lukács e Goldmann (LYNCH; CHALOUB, 2021). Uma vez que a investigação não deve ser apresentada necessariamente na ordem em foi feita (no caso, "de frente para trás”), a fim de tornar a sua exposição mais lógica, os resultados da pesquisa serão aqui apresentados em ordem cronológica, do período mais remoto ao mais recente.

\section{De Hegel a Angell: idealismo e realismo na formação e apogeu do paradigma "metafísico" de política (1770-1914)}

Desde a Antiguidade a vida em sociedade foi objeto de reflexões sobre a natureza do poder ou a melhor forma de governo. O seu conjunto atende pelos nomes de ciência política, filosofia política, teoria política, pensamento político, história do pensamento político, história das ideias políticas ou história das doutrinas políticas (CASTIGLIONE; HAMPSHER-MONK, 2001). Na tentativa de oferecer um mapa desse cipoal de 2.500 anos, os historiadores do pensamento político formularam classificações destinadas a lhe conferir alguma inteligibilidade preliminar. A mais popular foi 
a divisão binária dos teóricos entre os chamados idealistas, para quem a "ciência política" deve ser conduzida normativamente, ou seja, conforme imperativos éticos, e os realistas, que preferem compreendê-la descritivamente, isto é, conforme a "verdade efetiva" do poder. Essa divisão atravessa pelo menos três diferentes "paradigmas" de ciência política entendidos à maneira de Thomas Kuhn (1997). Embora as denominações "idealistas" e "realistas" ainda não existissem no paradigma renascentista/seiscentista, já se disputava em torno da natureza de ciência política em termos semelhantes. Para os teóricos da razão de Estado, a ciência política deveria ser "útil", limitando-se a descrever as técnicas concretas de exercício do poder. Em O príncipe (1513), Maquiavel entendia serem lícitos ao governante todos os meios facultados pela força e pela inteligência (virtù), desde que empregados com habilidade e conforme as circunstâncias (fortuna) (MAQUIAVEL, 2001, p. 85). Em suas Considerações sobre os golpes de Estado (1663), Gabriel Naudé também desprezava a abordagem normativa da escolástica, preferindo descrever "os maiores segredos das monarquias, as intrigas das cortes, as cabalas dos facciosos, os pretextos e motivos particulares" (NAUDÉ, 1667, p. 41). Os escolásticos não admitiam a política desvinculada dos preceitos e fins da moralidade cristã, entendendo que ela precisava ser "honesta" para a manutenção da paz e da justiça. Por isso, Francisco Suárez sustentava, na sua Defesa da fé católica (1613), que as doutrinas da razão de Estado eram "insanas" e "ímpias", sem "valor algum para a conservação de uma república ou reino temporal” (SUÁREZ, 2015).

Embora o novo paradigma que emerge do Iluminismo setecentista tenha passado a tratar a ciência política no registro secularizado, nem por isso deixou de renovar os seus vínculos com a moralidade, inscrevendo-a agora no plano da metafísica. A filosofia da história de Hegel foi a sua principal fonte idealista de intelecção, ao conceber o conhecimento como uma sucessão de etapas do progresso do Espírito Absoluto refletidas nas obras dos grandes homens: 
A história da filosofia expõe-nos a galeria dos nobres espíritos que, graças à ousadia da sua razão, penetraram na natureza das coisas do homem, e na natureza de Deus, desvelaram-nos a sua profundidade e para nós elaboraram o tesouro do mais alto conhecimento (HEGEL, 2006, p. 13).

No contexto da recepção de Hegel na França, caberia a François Guizot apresentar, na sua História da civilização na Europa (1828), a autoridade e a liberdade como dois princípios em luta no processo histórico:

Duas grandes forças e dois grandes direitos, a autoridade e a liberdade, coexistem e se combatem naturalmente no seio das sociedades humanas [...], sem jamais se reduzirem mutuamente à impotência, sujeitas uma e outra às oscilações, a retornos de fortuna que fizeram, através de uma longa série de séculos, o destino dos governos e dos povos (GUIZOT, 1855, p. XIII).

Não demorou para que a defesa da autoridade ficasse identificada a uma posição realista ou conservadora, e a da liberdade, a uma posição idealista ou progressista. Na sua História da ciência política em suas relações com a moral (1872), Paul Janet argumentava que os idealistas defendiam a normatividade como horizonte regulador da política, crentes na perfectibilidade moral e intelectual dos seres humanos, revelada por uma história de caráter progressivo. Já os realistas advogavam fórmulas políticas extraídas da prática e da tradição, acreditando na imutabilidade da natureza humana, revelada por uma história de caráter pragmático. Entre os dois extremos, julgados nocivos, Janet propunha um idealismo prático identificado com as obras de Montesquieu e Tocqueville, entendido como síntese entre realismo e idealismo:

O verdadeiro político não é um filósofo como o pensava Platão, mas um filósofo que sabe que o reino da filosofia não é deste mundo, e que é preciso tratar os homens tais como 
eles são, a fim de conduzi-los pouco a pouco àquilo que eles devem ser (JANET, 1872, p. XL).

Em sintonia com a cultura europeia, para se identificarem politicamente, os políticos brasileiros do século XIX também se valiam da dicotomia que opunha "idealistas" a "realistas". Era a partir dela que o senador Bernardo Pereira de Vasconcelos distinguia positivamente os conservadores dos liberais: "Nós não somos os homens das teorias, os homens dos sistemas, os homens das utopias; somos os homens da prática, os amigos das realidades" (ASI, 7/10/1843). Essa posição, que associava ao conservadorismo a sensibilidade ao real, seria reiterada no Ensaio sobre o direito administrativo (1862) por seu principal discípulo, o visconde do Uruguai:

Erram [...] aqueles que, abstraindo do estudo e comparação das circunstâncias expostas [...], atêm-se somente a uma ou outra consideração teórica, destacada e declamatória. Para se julgar as instituições, é preciso atender aos tempos e às circunstâncias (SOUSA, 2002, p. 428).

Trinta anos depois, seria a vez de Joaquim Nabuco condenar, em Balmaceda (1895), a "política silogística" do radicalismo, dogmático e ignorante das circunstâncias concretas da ação política: "É uma pura arte de construção no vácuo. A base, são teses, e não fatos; o material, ideias, e não homens; a situação, o mundo, e não o país; os habitantes, as gerações futuras, e não as atuais" (NABUCO, 1949, p. 17). Em Um estadista do Império (1897), ele examinaria as atitudes ideológicas dos políticos brasileiros a partir dos mesmos arquétipos: "Teixeira de Freitas era, em relação ao direito, um nominalista; Nabuco [de Araújo], um realista" (NABUCO, 1997, p. 1073). Leitor de Paul Janet, o intelectual pernambucano também se dizia partidário de um idealismo prático à maneira de Tocqueville, conforme declarava em Escritos e discursos literários (1901): "A regra de conduta, em moral política, não é querer realizar um ideal 
absoluto, mas tê-lo diante de nós como um ponto fixo, de modo que caminhemos sempre para ele" (NABUCO, 1901, p. 610).

$\mathrm{Na}$ Alemanha recém-unificada, em suas Conferências sobre Política (1899), o conservador Heinrich von Treitschke denunciava o "cosmopolitismo passivo" dos idealistas como "imoral e impolítico ao mesmo tempo" e saudava o conflito e a guerra como fenômenos intrínsecos à natureza humana (TREITSCHKE, 1914, p. 34). O seu nacionalismo serviria de base para a primeira grande obra de Friedrich Meinecke, Cosmopolitismo e Estado Nacional (1907), que justificava o fortalecimento nacional pelo Estado como decorrência de uma exigência de "objetividade" científica: "Devemos levar a empiria como um objetivo em si e persegui-lo incansavelmente" (MEINECKE, 1970, p. 43). As nações não surgiam de princípios abstratos, mas de forças históricas concretas, reunidas e coordenadas pelas elites dirigentes. Cada uma delas era descrita por Meinecke como uma espécie de singular coletivo, dotada de uma cultura particular. A rivalidade entre eles era julgada benéfica, porque fortaleceria suas respectivas identidades. Partindo da premissa de que o Estado nacional era a ideia mais poderosa do pensamento moderno, e que uma história intelectual deveria se concentrar nas personalidades responsáveis pelo seu desenvolvimento, Meinecke afirmava haver duas linhagens políticas na Alemanha. A primeira era formada de idealistas como Humboldt e Schlegel, alheios à questão nacional. Eram eles os liberais-democratas, os conservadores românticos e os socialdemocratas, todos de orientação cosmopolita e afrancesada. A segunda família intelectual era composta por realistas como Hegel e Bismarck, integrantes de uma "corrente conservadora" interessada em fortalecer o Estado prussiano, visto como responsável por aglutinar uma nação alemã dispersa por diversas unidades territoriais. A história das ideias políticas contida em Cosmopolitismo e Estado Nacional terminava assim por justificar a renovação a orientação "realista" que conduzira o processo de unificação da Alemanha, clamando pelo advento de um novo Bismarck.

Mas, ao contrário do que pode sugerir uma leitura ingênua dos autores "realistas", os "idealistas" recusavam a carapuça de "utopistas" 
atiradas por seus adversários, defendendo o "realismo" de suas posições progressistas. Replicavam que, presos a uma concepção estática da natureza humana, os "realistas" se revelavam incapazes de compreender a natureza dinâmica da realidade política. Norman Angell explicava em A grande ilusão (1910) que a "globalização" em curso desde as últimas décadas do século XIX tornara os indivíduos e as nações cada vez mais interdependentes e, portanto, inclinados a atitudes progressistas, cosmopolitas e democráticas:

Todo progresso no sentido da civilização se verifica às custas do espírito militar, e à medida que declina a tendência à luta, desenvolve-se a inclinação para o trabalho. A nação progride mediante a cooperação das pessoas, que trabalham umas com as outras em vez de digladiarem-se (ANGELL, 2002, p. 192).

Os conflitos modernos já não eram entre as nações, e sim "entre a democracia e a autocracia, ou entre o socialismo e o individualismo, a reação e o progresso" (ANGELL, 2002, p. 164-165). Incapazes de perceberem a nova realidade saída da globalização, pretensos "realistas" como Treitschke, Nietzsche e Le Bon veiculavam o discurso xenófobo e protecionista responsável pelo “atraso das nossas ideias políticas em comparação com as outras noções que orientam atualmente a nossa vida" (ANGELL, 2002, p. 170). Nos Estados Unidos, era o pragmatismo de John Dewey que combatia os "espíritos reacionários". Em Liberdade e Cultura (1939), ele afirmava que somente de espíritos "interessados na realidade" se poderia esperar iluminação e direção (DEWEY, 2008, p. 32-133). Em outras palavras, os intitulados "realistas” é que eram “irrealistas". A concepção estática do homem como animal eternamente guerreiro e belicoso dos "realistas" é que era, para os progressistas, uma "grande ilusão":

A alegada estabilidade da estrutura da natureza humana não explica, em coisa nenhuma, as diferenças que marcam uma tribo, uma família ou um povo de outros; o que implica em 
dizer que, nem em si, nem por si, pode explicar qualquer estado social, não adverte sobre nenhuma política mais vantajosa a seguir e nem justifica, tampouco, o conservantismo contra o radicalismo. A pretensa imutabilidade da natureza humana não pode ser admitida; pois ainda que constantes algumas das suas necessidades, as consequências que produzem (face ao estado de cultura existente, da ciência, da moral, da religião, da arte, da indústria, das normas jurídicas) reagem sobre os próprios componentes originais para ajustá-los a formas novas. E, com isso, o padrão primitivo e total sofre modificações (DEWEY, 1953, p. 132-133).

O debate travado nos termos dicotômicos que opunham "realistas" e "idealistas" adentrou o século XX brasileiro. Defendendo posições análogas às de Angell, Alberto Torres afirmava em seu Discurso de posse no Instituto Histórico e Geográfico (1911) que "o ideal, que não se confunde com a utopia, não é senão o extremo indefinido do futuro que há de ser alcançado por uma linha reta, tendo por ponto de partida um sentimento humano" (TORRES, 1911, p. 558). O presidente do instituto, o conde de Afonso Celso, respondeu-lhe à maneira de Treitschke: a natureza humana era irremediavelmente belicosa e a paz no mundo só poderia ser mantida por uma contínua preparação para a guerra (TORRES, 1911, p.596-601). Durante a Grande Guerra de 19141918, seria a vez de Rui Barbosa defender a posição idealista em $O$ Dever dos Neutros (1916): "As doutrinas precedem aos atos. Os fatos materiais emanam dos fatos morais" (BARBOSA, 1984, p. 49). O Brasil deveria seguir o exemplo de idealismo fornecido pelos EUA e pela Grã-Bretanha, vanguarda histórica de todos os "povos pacíficos, as nações liberais, os governos democratizados" (BARBOSA, 1984, p. 60). Por sua vez, em $O$ idealismo na evolução política do Império e da República (1922), Oliveira Vianna acusaria o cosmopolitismo liberal de Rui de ignorar "as condições reais e orgânicas das sociedades que pretendem reger e dirigir". Contra o idealismo utópico típico dos liberais brasileiros, Vianna propunha resgatar o 
idealismo orgânico dos estadistas conservadores do Império, como Vasconcelos e Uruguai, alimentado somente da "realidade, que só se apoia na experiência, que só se orienta pela observação do povo e do meio" (VIANNA, 1922, p. 14-17). Como se percebe, a posição de Oliveira Vianna no Brasil era análoga àquela de Meinecke na Alemanha: o parâmetro da realidade política de uma nacionalidade ainda balbuciante não poderia ser o da mera liberdade individual, entendida em uma perspectiva cosmopolita, e sim de um Estado forte, comandado por elites patrióticas e esclarecidas.

\section{De Marx a Mannheim: idealismo e realismo na formação do "paradigma científico" de política (1870-1970)}

A aceleração do processo de secularização, de desenvolvimento científico e de ampliação do eleitorado solapou no último terço do século XIX a credibilidade do paradigma metafísico da ciência política. Contra a concepção idealista da política liberal, correntes cientificistas como o marxismo, o positivismo e o evolucionismo reivindicavam a descoberta de um "motor da história" de caráter exclusivamente materialista: a luta de classes; o progresso da ciência e a luta pela vida, respectivamente (HAYES, 1941, p. 50). Das três correntes, aquela que fez mais estragos no casco do liberalismo foi o marxismo. Em A ideologia alemã (1846), Marx sustentava que, ao contrário do que pressupunha Hegel, o mundo real não era determinado pelas ideias, mas pelas relações materiais decorrentes dos diferentes modos de produção: "Os pensamentos dominantes não passam da expressão ideológica das relações materiais dominantes" (MARX, 1975, p. 92). O materialismo histórico apontava a realidade política como um produto do antagonismo entre as classes dominantes e dominadas, derivado do monopólio privado dos bens de produção. Mas não havia correspondência automática entre a realidade material e as representações daquela realidade. Marx ressemantizou então o conceito de ideologia, empregando-o para designar o conjunto de crenças ou representações socialmente incongruentes: "Como em toda a ideologia, os homens e seus vínculos aparecem diante de nós de ponta-cabeça, como em 
uma câmara escura" (MARX, 1968, p. 36). Ele também recorria ao conceito de alienação, igualmente ressemantizado, para explicar o conformismo das classes exploradas com sua situação de ignorância e passividade, justificada pela "ideologia burguesa" do liberalismo, entendido como "idealismo". Único sistema de pensamento capaz de expressar fielmente a "realidade", só o marxismo poderia emancipar os trabalhadores oprimidos, denunciando a ideologia, cancelando a alienação e despertando-os para o programa comunista. Desnudar a realidade da luta de classes ao longo da História era indispensável para a promoção do avanço igualitário: "Sem antagonismo não há progresso. Esta é a lei que a civilização seguiu até a atualidade" (MARX, 1975, p. 115).

O primeiro esboço da "nova” ciência política que se tornaria hegemônica no século 20 surgiu na Itália, todavia. A partir de uma pretensão de neutralidade que se opunha tanto ao idealismo quanto ao materialismo, ela pretendia estudar o fenômeno político sem se confundir com qualquer das ideologias em pugna. Gaetano Mosca, Vilfredo Pareto e Roberto Michels, mas também Gustave Le Bon e Georges Sorel, viriam a ser conhecidos como elitistas por desmentirem como irrealizáveis os ideais democráticos de autogoverno. A história e a observação dos fatos em todos os tempos e quadrantes demonstravam que a maioria da população sempre havia sido dominada por uma minoria, formada por uma elite ou classe dirigente (BOBBIO, 2002, p. 17). Os elitistas postulavam a estabilidade da natureza moral dos homens, que se orientavam antes por seus instintos e paixões, do que pelo conhecimento objetivo da realidade. A sociedade era conflituosa; e a política feita de coerção e violência. As ideologias serviam apenas para encobrir a ambição de poder ${ }^{8}$. Em seus Elementos de ciência política (1896), Mosca denominava fórmulas políticas ao "conjunto de doutrinas e crenças que

8 "Apesar das nuances e até importantes distâncias nas visões políticas desses três pensadores, todos convergem na descrição da democracia liberal como regime utópico cuja rotina institucional não guarda vínculos com sua motivação ideal. Nessa perspectiva, as ideias de soberania popular, igualdade política e sufrágio universal compõem um universo abstrato de discurso, sem sustentação real. Na percepção elitista, todo exercício da política, alheio às suas justificativas formais, está fadado a formação de pequenos grupos que subordinam a maior parte da população." (HOLANDA, 2011, p. 10) 
dão fundamento moral ao poder dos dirigentes", periodicamente modificadas para acompanhar as alterações na forma e na organização da classe política (MOSCA, 1987, p. 12). Em seu Tratado de sociologia geral (1916), Pareto também explicava as crenças como derivações voltadas para justificar publicamente ações cuja motivação, na verdade, radicava nos resíduos, isto é, os instintos mais reprováveis do homem (PARETO, 1984, p. 66). Na impossibilidade de desfazer as ilusões ideológicas que moviam as massas, os governantes deveriam instrumentalizá-las para preservar a ordem - premissa que traía as posições conservadoras dos elitistas, ocultas sob o véu de "realismo científico":

A estabilidade social é de tal maneira benéfica que para mantê-la vale bem a pena recorrer à ajuda de ideais fantásticos desta ou daquela teologia - entre outras, a teologia do sufrágio universal - e resignar-se a aguentar certas desvantagens. Antes que seja aconselhável perturbar a paz pública, tais desvantagens devem ter-se tornado muito sérias; e já que os seres humanos são guiados não pelos raciocínios céticos da ciência, mas por 'fés vivas' expressadas em ideais, teorias como o direito divino dos reis, a legitimidade das oligarquias, do 'Povo', da 'maioria', das assembleias legislativas, e outras coisas como estas, podem ser úteis até certo ponto, e de fato provaram ser, não importa quão absurdas possam ser do ponto de vista científico (PARETO, 1966, p. 88).

O rechaço do paradigma metafísico de política como "ingênuo" ou idealista, por parte de marxistas, positivistas e elitistas, serviu assim para a emergência de outro, que encontraria sua expressão mais característica na sociologia do conhecimento de Max Weber., Sua teoria da modernidade, entendida como produto de uma racionalização decorrente da secularização do mundo, rompia a antiga unidade cognoscitiva entre natureza e cultura, que havia sido preservada pelo cientificismo de Comte, Marx e Spencer. Para Weber, era ilusória a perspectiva teleológica dos materialistas, segundo 
a qual a ciência desvelaria a "realidade" do universo ao cabo do processo histórico. Mesclando descrição e normatividade, as filosofias materialistas da história transformavam "ciência" em teologia, e "crítica", em revelação (ROTH; SCHLUCHTER, 1984, p. 50-51). Uma vez que a ciência social não podia conferir sentido à sociedade de um mundo secularizado, ela deveria limitar-se a compreender as motivações subjetivas da ação, que eram orientadas pelos valores presentes na cultura. Essa sociologia compreensiva somente poderia ser praticada de forma especializada, por profissionais treinados para investigar problemas e orientados por um ideal de neutralidade axiológica. Desvinculada primeiro da religião e, agora, da ciência, a política ficava na dependência exclusiva das decisões tomadas pelos homens, a partir de seus próprios juízos morais. Sem deuses, os líderes deveriam a assumir sua responsabilidade pelos destinos dos povos. Em A política como vocação (1919), Weber apostava no "idealismo prático" ao recomendar aos estadistas que guardassem "o senso das proporções", adequando suas convicções às circunstâncias concretas da ação: "A ética da convicção e a ética da responsabilidade não se contrapõem, mas se completam e, em conjunto, formam o homem autêntico, isto é, um homem que pode aspirar à vocação política” (WEBER, 2006, p. 122).

De modo análogo ao "realismo" elitista, Weber reconhecia haver em todas as formas de governo uma minoria que dominava pela coação e por mecanismos tradicionais, carismáticos ou racionais-legais de legitimação ideológica. Em Economia e sociedade (1922), ele reconhecia igualmente que a política não tinha fins altruístas, sendo ela essencialmente "a luta, a conquista de aliados e de um séquito voluntário" (WEBER, 1999, p. 562). O Estado era o aparato que monopolizava o exercício legítimo da violência para a minoria de dominadores. Enquanto a burocracia uniformizava cada vez mais a sociedade e o mercado, a democracia perigava converter-se em uma ditadura fundada na emotividade das massas. Mas, ao contrário de Pareto e Mosca, Weber não acreditava que a democracia fosse uma "ilusão". Ela era produto de um longo processo de racionalização que, trazendo a reboque o desenvolvimento científico, 
capitalista e burocrático, criara um mundo novo, individualista e igualitário. Encarada no quadro mais amplo de todas aquelas mudanças sociais e econômicas, a democracia era antes de tudo um enigma a ser decifrado. Ele se perguntava: "Quais as consequências desta democratização progressiva dos meios e das organizações da luta política para as formas de atividade política?" (WEBER, 1999, p. 570). A política era a arena das disputas ideológicas, a que a ciência deveria se manter o tanto quanto possível neutra por meio de rigoroso controle metodológico. Daí se extraiam dois corolários. Em primeiro lugar, não era mais possível admitir a existência de uma ideologia "realista" do ponto de vista científico, condenando-se as demais como "idealistas". Em segundo lugar, não cabia à ciência valorar as doutrinas, seja de modo negativo ou positivo. Socialismo, liberalismo e conservadorismo eram visões de mundo que orientavam a ação política em uma sociedade de massas, que não podia existir sem crenças. Assim, embora o socialismo marxista, do ponto de vista científico, parecesse uma "fé escatológica econômica" que prometia "salvação do domínio de classe", do ponto de vista democrático, ela era perfeitamente compreensível. Nem por isso, em Sufrágio e democracia na Alemanha (1917), Weber deixava de expressar o seu desgosto por "literatos", cujas atitudes moralistas compunham "um quadro tão repugnante de falta de objetividade, de ausência de juízo político e de cegueira deliberadamente cultivada perante as realidades" (WEBER, 2014, p. 138).

A distinção entre ciência e ideologia não significava que o acadêmico não pudesse interagir com o mundo público. Havia duas formas possíveis de interação consequente. A primeira era atuando como técnico. Se a ciência não servia para a tomada de decisões de caráter ético, ela poderia contribuir para elevar a qualidade das escolhas, oferecendo ao político um quadro mais objetivo das circunstâncias em que elas teriam lugar. A ciência política poderia assim desestimular decisões irresponsáveis, motivadas por ideologias radicais e irrealistas, em função da sua inviabilidade, inoportunidade ou inconveniência. A segunda forma de interação responsável do cientista com a política, por sua vez, passava pela assunção da condição 
de "intelectual público". O cientista abandonava então sua torre de marfim de forma consciente para tecer considerações públicas, na qualidade de cidadão. Na nota preliminar de Parlamento e governo na Alemanha reorganizada (1918), Weber advertia: "Este tratado político [...] não se reveste da autoridade de uma ciência, pois as últimas posições tomadas pela vontade não podem ser decididas por meios científicos" (WEBER, 2014, p. 167). Respaldado por seu lugar de fala profissional, o cidadão Weber criticava todas as ideologias presentes no debate alemão de seu tempo. O conservadorismo parecia cego às mudanças sociais, confessando sua impotência no contexto democrático ao clamar por novo tutor para o país. $\mathrm{O}$ liberalismo havia se tornado anacrônico, incapaz de se livrar de sua metafísica burguesa. $\mathrm{O}$ socialismo revolucionário padecia de óbvios resquícios teológicos e escatológicos. Por outro lado, Weber admitia a produtividade do nacionalismo moderado e do socialismo revisionista na organização de uma "democracia bem ordenada" . Embora o seu "realismo" não acreditasse na possibilidade de erradicação do conflito ideológico, ele acreditava na educação para a democracia e no bom funcionamento das instituições parlamentares para moderar o radicalismo e favorecer soluções negociadas.

Como intelectual público, portanto, Weber defendia implicitamente um liberalismo novo, "realista", porque livre de seus antigos compromissos oligárquicos e plutocráticos. A despeito de sua justificação originalmente metafísica, o liberalismo não era uma relíquia pré-moderna, mas uma consequência da racionalização da vida, que deveria se adequar no quadro novo de uma democracia social à sociedade de massas e ao capitalismo industrial (MAYER, 1985,

9 Essa posição é dedutível da análise sistemática de diversas passagens de seus textos: "Sempre existirão partidos'conservadores', porque sempre haverá pessoas com fortes tendências autoritárias" (WEBER, 2014, p. 137). "As realidades implacáveis do presente cuidarão para que as árvores da democracia antiquada, negativa e que do Estado só exige a liberdade não cresçam até alcançar o céu" (WEBER, 2014, p. 137). Ele também denunciava, no campo da esquerda radical, "o romanticismo da greve geral e o romanticismo da esperança revolucionária" (WEBER, 2014, p. 376). Mas reconhecia que o problema do socialismo estava menos em si do que em torná-lo compatível com a democracia liberal: "Não há nenhuma maneira de eliminar do mundo a convicção e as esperanças socialistas. Todo operariado sempre será em algum sentido socialista. A pergunta é se esse socialismo será de um tipo tolerável, do ponto de vista dos interesses do Estado" (WEBER, 2014, p. 382). 
p. 41; ELIAESON, 2000, p. 132). A sua preocupação em resguardar o catálogo de liberdades individuais contra a burocracia do Estado era constante:

Como será possível salvar ainda pelo menos alguns restos de uma liberdade 'individual' de ação em algum sentido, considerando essa tendência superpoderosa rumo à burocratização? Pois, afinal de contas, é um grande autoengano a ideia de que hoje possamos viver sem essas conquistas dos tempos dos 'direitos humanos' (nem a pessoa mais conservadora pode) (WEBER, 2014, p. 204).

Ao contrário dos elitistas, Weber encarava os políticos profissionais como instrumentos de estruturação democrática. A sobrevivência da democracia liberal dependia de um sistema partidário e parlamentar competitivo, capaz de selecionar políticos de qualidade: "Somente a liderança ordenada das massas por parte de políticos responsáveis pode romper a dominação desordenada pela rua e a liderança de demagogos fortuitos" (WEBER, 2014, p. 160). As instituições da "democracia bem ordenada" filtravam os conflitos, adotando regras que impeliam os atores a resolver suas desavenças, não pelo radicalismo, mas por soluções de compromisso: “Toda a política radicalmente orientada em geral é a capacidade de perder oportunidades" (WEBER, 2014, p. 83). Na prática, a conciliação entre as éticas da responsabilidade e da convicção apregoada por Weber renovava, para o contexto democrático e industrial, o elogio da prudência como "justo meio" feito por liberais que também enxergavam a política no cruzamento da história e cultura Tocqueville, notadamente.

Karl Mannheim se encarregaria de levar adiante as orientações de Weber, especialmente nas relações envolvendo ciência e ideologia. Na edição definitiva de Ideologia e utopia (1936), ele explicava a ideologia como um produto da sociedade de classes. A política era o campo de disputas entre ideologias concorrentes: conservadorismo, liberalismo humanitário e socialismo comunista. Embora cada uma 
delas estivesse vinculada a uma classe (aristocracia, burguesia e proletariado, respectivamente), nenhuma seria inteiramente verdadeira. Crítico das perspectivas normativas, Mannheim apostava na constituição de uma "ciência política" situada em um "centro dinâmico" comprometido com o ideal possível da neutralidade axiológica. Uma intelligentsia, menos contaminada por condicionamentos de classe, seria capaz de estudar em seus respectivos contextos sociais os diferentes conhecimentos políticos representados por cada ideologia. Ela deveria

[...] ultrapassar a discussão sem reconhecimento dos vários antagonistas, assumindo como seu tema explícito de investigação, a descoberta das origens dos desentendimentos parciais que nunca seriam percebidos pelos disputantes, devido à sua preocupação com o assunto imediato em debate (MANNHEIM, 1972, p. 303).

Embora nenhuma ideologia política fosse "realista" ou "idealista" do ponto de vista científico, todas eram legítimas como objeto de estudo. Entre elas, Mannheim identificava ainda mentalidades utópicas, desejosas de romper com o estado de coisas; e outras, ideológicas, justificadoras do status quo. A distinção entre a ciência praticada por uma intelligentsia profissional (ciência) e o conhecimento político veiculado pelos atores (ideologia) permitiria a estes últimos se aperceberem de suas diferenças no registro da reciprocidade, educando-os para uma cultura de tolerância que reduzisse o radicalismo irracionalista identificado com o comunismo e o fascismo. A moderação aclimataria uma democracia social, justo meio em qual Mannheim também depositaria suas esperanças em sua grande obra póstuma: Liberdade, poder e planificação democrática (1950). A perspectiva de Mannheim foi recepcionada no meio de fala inglesa quando, emigrado na Inglaterra, ele publicou uma versão de Ideologia e Utopia adaptada ao público anglo-americano. O longo prefácio escrito por Louis Wirth, professor da Universidade de Chicago, fez a mediação entre as tradições sociológicas 
alemã - culturalista e historicista - e a anglo-americana - pragmatista e utilitarista (MAZUCATO, 2014, p. 158).

\section{Liberalismo, nacionalismo e marxismo: três modelos de história intelectual}

Conforme já examinado, o rechaço do paradigma "metafísico" de política surgido à época do Iluminismo como "ingênuo" ou "idealista", por parte de marxistas, positivistas e elitistas, serviu para a emergência de outro que, em diálogo crítico com aquelas três correntes, encontrou sua expressão mais acabada na sociologia do conhecimento de Max Weber. Entretanto, enquanto Mannheim a desenvolvia para criar o seu próprio modelo de estudo das ideologias políticas, outros dois ex-alunos do autor de Economia e Sociedade reinterpretaram criticamente a sua proposta de ciência social, recusando a pretendida possibilidade de disjunção entre fatos e valores. Se Carl Schmitt reinterpretou o paradigma científico de Weber pelo lado da direita, recorrendo às doutrinas da razão de Estado, do absolutismo e do reacionarismo, Gyorgy Lukács o releu pelo lado da esquerda, apelando ao socialismo marxista de matriz hegeliana. Recusaram a caraterização do fenômeno político a partir de uma matriz pluralista, que comportasse a existência de pelo menos três ideologias ou correntes de opinião. Preferiram outra, que descrevesse o conflito político como reduzido a dois polos irredutivelmente antagônicos, fossem amigos e inimigos em torno da questão nacional, ou proletariado e burguesia no quadro da questão social. Essa concepção de política como um conflito intenso, permanente e inarredável entre dois campos levaria à produção de modelos de história intelectual que, a despeito de seu propalado "realismo" científico, acabaram por reproduzir a visão dicotômica do paradigma metafísico, ao dividir o espectro político entre idealistas ou realistas. Depois da Segunda Guerra Mundial, vários liberais também voltaram a defender doutrinariamente o liberalismo como a única tradição que "verdadeiramente" correspondia à "realidade" histórica da política. Emergiram, assim, no seio do novo paradigma científico de política, três modelos de 
história intelectual ideologicamente comprometidos: o liberal, o nacionalista e o marxista.

\section{O "modelo liberal" de história das ideias políticas}

A obra de Mannheim impactou diversas obras no meio acadêmico da ciência política. A primeira delas foi provavelmente o clássico de Edward H. Carr, Vinte anos de crise 1919-1939 (1939), que buscava reestruturar o estudo da teoria política a partir do novo paradigma científico de ciência social. Tendo como exemplo negativo de utopismo liberal A grande ilusão, de Norman Angell, o internacionalista britânico explicitava seu objetivo da seguinte maneira: "A ciência política deve ser baseada no reconhecimento da interdependência da teoria e da prática, que só pode ser atingida através da combinação de utopia e da realidade" (CARR, 2001, p. 20). Ele fundava assim abertamente sua pretensão de cientificidade na sociologia compreensiva de Mannheim, recorrendo também ao "realismo" de Reinhold Niebuhr, que nos Estados Unidos criticava o idealismo de progressistas como John Dewey. Em seu livro, Carr aplicava, ao estudo da ciência política, pares conceituais antitéticos expressivos de abordagens utópicas e realistas: utopia e realidade; teoria e prática; radicalismo e conservadorismo; idealismo e pragmatismo; internacionalismo e nacionalismo. A corrente utópica ou idealista, representada por personalidades de tendência liberal e radical - como o Abade de Saint-Pierre, Kant, Saint-Simon, Comte e Woodrow Wilson -, seria movida por uma visão universalista e abstrata da política. Ela acreditava contribuir para uma ordem mais justa, forçando a aceleração de um processo histórico marcado pelo desenvolvimento moral. Já a corrente realista, integrada por conservadores como Maquiavel, Hobbes e Clausewitz, alimentaria uma visão empírica da política condicionada pelo passado. Para eles, a história obedecia a leis de causalidade orientadas pela luta pelo poder, que não poderiam ser modificadas por nenhuma vontade particular. Carr criticava ambas as abordagens: o idealismo incorria na pecha de ingenuidade por negligenciar os meios práticos conducentes ao aprimoramento da ordem, ao passo que, ao descrer nas 
potencialidades de progresso embutidas no processo histórico, o realismo redundava em completa esterilidade moral. Ele recomendava, pois, um meio termo, capaz de colocar a epistemologia científica - realista - a serviço do ideal - utópico - de justiça:

Coerção e consciência, inimizade e boa vontade, autoafirmação e autossubordinação, estão presentes em toda a sociedade política. O Estado é construído a partir desses dois aspectos conflitantes da natureza humana. Utopia e realidade, o ideal e a instituição, moral e poder, estão, desde o início, inextrincavelmente combinados nele [...] O utópico, que sonha ser possível eliminar a autoafirmação da política, e basear um sistema filosófico unicamente na moral, está tão distante dos fatos quanto o realista, que crê que o altruísmo seja uma ilusão, e que toda ação política seja baseada no interesse próprio [...]. Não se pode divorciar política de poder (CARR, 2001, p. 129).

Na França, era Raymond Aron que advogava a causa do "realismo" em Paz e Guerra entre as Nações (1962). Responsável pela introdução de Weber na França e pelo resgate de Tocqueville do esquecimento, Aron acreditava que "a necessidade do egoísmo nacional deriva do 'estado de natureza' ou 'estado natural' que prevaleceria no relacionamento entre as unidades políticas soberanas" (ARON, 2002, p. 705). Ele denunciava assim os males da "ilusão idealista" oitocentista, que, supostamente, ignorava o primado político da força. Tratava-se de uma ilusão epistemológica, manifestada tanto por um "idealismo ideológico", satisfeito com a crença de que a ideia fosse o critério exclusivo e suficiente da definição do justo e do injusto, quanto por um "idealismo jurídico", que superestimava o papel do direito na tomada de decisões (ARON, 2002, p. 706). Em contrapartida, os realistas se conduziam pela "virtude suprema do estadista": a prudência, a qual dispensava o principialismo e o espírito de sistema. O estadista orientava-se "em função da singularidade da situação e dos dados concretos disponíveis" (ARON, 2002, p. 709). 
No entanto, de acordo com Aron, o "realismo" da prudência não se opunha ao "idealismo", compreendido como a aspiração a um futuro melhor, mas tão somente à "ilusão idealista, seja ela jurídica ou ideológica” (ARON, 2002, p. 710). Havia espaço, portanto, para um idealismo moderado, realista, expressivo de uma aspiração legítima de "respeito às ideias, a aspiração a valores elevados, a preocupação com as obrigações contraídas" (ARON, 2002, p. 737). Tanto quanto Carr, Raymond Aron era, desse modo, fiel ao ideal weberiano de uma ciência social localizada naquele "centro dinâmico" descrito por Mannheim, que evitava simultaneamente a utopia e a ideologia, e que saudava a democracia social como o horizonte natural do liberalismo moderno. Esta era uma posição que, a despeito de seus rechaços metafísicos, coincidia ideologicamente com o "idealismo prático" de liberais oitocentistas como Tocqueville e Paul Janet. Era o que Aron reconhecia, ao definir as ideologias políticas em $O$ ópio dos intelectuais (1955):

As ideologias políticas misturam sempre, com maior ou menor felicidade, julgamentos de fato e de valor. Elas exprimem uma perspectiva sobre o mundo e uma vontade voltada para o futuro. Elas não recaem diretamente sob a alternativa do verdadeiro e do falso, nem do gosto ou das cores. A filosofia última e a hierarquia de preferência pedem antes o diálogo do que a prova e a refutação; a análise dos fatos atuais ou a antecipação dos fatos vindouros se transforma com o desenrolar da história e o conhecimento que adquirimos. A experiência corrige progressivamente as construções doutrinárias (ARON, 1955, p. 246).

Contudo, diante da exigência ética de defender a democracia contra o bolchevismo e o fascismo depois da Segunda Grande Guerra, diversos liberais - especialmente radicados na Grã-Bretanha e nos Estados Unidos - retomaram uma abordagem doutrinária da história das ideias políticas, organizada a partir da dicotomia idealismo versus realismo. Exemplo dessa retomada foi a conferência 
Absolutismo e relativismo na filosofia e na política (1948), da autoria do cientista político e jurista austríaco Hans Kelsen. O seu ponto de partida era a suposta constância, na história da filosofia política, do "antagonismo entre o absolutismo e o relativismo filosófico" (KELSEN, 2000, p. 347). Identificado com o pensamento de Platão, o primeiro era definido como "a concepção metafísica da existência de uma realidade absoluta, i.e., uma realidade que existe independentemente do conhecimento humano". O absolutismo filosófico resultava na "personificação do absoluto, sua representação como o criador onipotente do universo cuja vontade é a lei da natureza assim como do homem" (KELSEN, 2000, p. 348). Esse tipo de filosofia desembocava na justificação do absolutismo político, gênero que abrangia o despotismo, a ditadura e a autocracia, ancoradas juridicamente no conceito de soberania absoluta. Já o relativismo filosófico, cujo principal epistemólogo teria sido Kant, fundamentava a liberdade e a igualdade como base da vida social e encontrava a sua contrapartida política na doutrina liberal. Enquanto os absolutistas eram "idealistas", porque metafísicos, sofistas e anticientíficos, os relativistas seriam os verdadeiros "realistas", por reconhecerem o pressuposto da liberdade humana. Em Fundamentos da democracia (1955), Kelsen defenderia a dimensão realista do liberalismo contra o decano do conservadorismo norte-americano, Reinhold Niebuhr. O mantra conservador de que liberais ignoravam a "natureza" humana não passava de uma caricatura:

Há muitos representantes do liberalismo, sobretudo economistas liberais, que levam plenamente em conta as tendências egoístas do homem e, em sua confiança na natureza humana, nenhum dos mais importantes filósofos liberais chegou ao ponto de considerar supérflua uma ordem coercitiva (KELSEN, 2000, p. 232).

De fato, intelectuais como Karl Popper e Friedrich Hayek também faziam então a defesa doutrinária do liberalismo como expressão de "realismo", substituindo seus fundamentos metafísicos por outros, 
extraídos da filosofia e da economia política. A oposição entre um "realismo" liberal e um "idealismo" totalitário atravessa obras de ambos, as mais paradigmáticas tendo sido $O$ caminho da servidão (1944) e A sociedade aberta e seus inimigos (1945). O antiliberalismo não passava de uma "grande utopia", que reivindicava para si um "espúrio realismo e até cinismo" (HAYEK, 1990, p. 32)

No Brasil da Guerra Fria, a deriva normativa dos liberais também levaria à elaboração de histórias intelectuais comprometidas com a "realidade política" da liberdade humana, muitas das quais redigidas por expoentes do partido liberal da época, a União Democrática Nacional (UDN). "Realistas" eram todos aqueles pensadores e políticos que reconheciam a liberdade como a essência mesma do regime democrático. Já os críticos do liberalismo, fossem socialistas ou conservadores, apareciam caracteristicamente etiquetados como “idealistas". Em sua História do direito constitucional brasileiro (1954), o jurista liberal Waldemar Ferreira acusava o ex-presidente Getúlio Vargas do "propósito malsão de introduzir no país o idealismo" de inspiração totalitária durante a ditadura do Estado Novo (FERREIRA, 1954, p. 111). Em Formação constitucional do Brasil (1960), Afonso Arinos de Melo Franco condenava ideólogos autoritários como Francisco Campos por sua obstinação "na defesa de soluções jurídicas irrealistas, que contrariavam a evolução da nossa História” (FRANCO, 1960, p. 151). A dicotomia estava implicitamente presente também na obra de outro liberal, Raymundo Faoro. Em Existe um pensamento político brasileiro? (1987), Faoro sustentava que o liberalismo seria a expressão ideológica de uma modernidade irrealizada no Brasil, devido à opressão de sua sociedade por um "estamento burocrático" de matriz ibérica, autoritário e patrimonialista. O "outro" do "verdadeiro" liberalismo, aqui ausente, existiria na forma do pseudoliberalismo conservador, que teria supostamente prevalecido no curso de toda a história nacional: "Os liberais do ciclo emancipador foram banidos da história das liberdades, qualificados de exaltados, de extremados, de quiméricos, teóricos e metafísicos" (FAORO, 1987, p. 54). Na medida em que a "realidade" moderna faltaria ao país, o Brasil não teria liberalismo: 
só um simulacro de pensamento político. Dedicado a Raymond Aron, O liberalismo antigo e moderno (1991) de José Guilherme Merquior já admitia ser "um livro liberal sobre liberalismo, escrito por alguém que acredita no liberalismo" (MERQUIOR, 2014, p. 37). Com o fim da Guerra Fria, o liberalismo voltara a ser veiculado por seus corifeus como o horizonte único e insuperável da realidade histórica: "A nossa sociedade permanece caracterizada por uma dialética continua, embora sempre em transformação, entre o crescimento da liberdade e o ímpeto sem direção a uma maior igualdade" (MERQUIOR, 2014, p. 264).

Elaborada durante a sua pós-graduação nos Estados Unidos, à luz das teorias de Juan Linz, a interpretação do pensamento político brasileiro formulada por Bolívar Lamounier reflete de modo fiel esse modelo liberal de história intelectual, crítico do autoritarismo ibérico e do ideário nacionalista (LYNCH; CASSIMIRO, 2018, p. 5-6). Em Formação de um pensamento autoritário na Primeira República (1977), Bolívar propugnava a existência de duas famílias intelectuais no período republicano: a autoritária e a liberal. Autoritários como Alberto Torres, Oliveira Vianna, Francisco Campos e Azevedo Amaral se guiariam por uma "ideologia de Estado" que se contrapunha àquela autenticamente liberal e própria da democracia, que tinha o mercado por matriz organizadora. Desprezando as condições históricas que levavam ao amadurecimento do sistema representativo, os autoritários preferiam que a sociedade, considerada imatura, fosse tutelada por um Estado tecnocrático, apresentado como superior a ela do ponto de vista étnico-cognitivo (LAMOUNIER, 1981, p. 244). Os verdadeiros "realistas" no Brasil teriam sido liberais como Tavares Bastos, Rui Barbosa e Sérgio Buarque de Holanda, que apostavam na construção da democracia a partir do amadurecimento de suas instituições e de sua cultura. Bolívar se dizia surpreso com a ingenuidade dos pretensos "realistas", cujo autoritarismo acreditava poder centralizar um país como Brasil, marcado pelo baixo grau de urbanização e por incapacidades estruturais de transportes e de arrecadação (LAMOUNIER, 1981, p. 241). Em escritos posteriores, como Rui Barbosa e a 
construção institucional da democracia brasileira (1999), e Tribunos, profetas e sacerdotes: intelectuais e ideologias no século XX (2014), Bolívar compararia a atuação dos intelectuais brasileiros com a dos norte-americanos e europeus, em seus respectivos contextos nacionais. Enquanto o liberalismo era definido por ele como a ideologia "do capitalismo e da democracia", o "antiliberalismo" compreenderia o fascismo e o comunismo, com "suas respectivas ramificações e derivações” (LAMOUNIER, 2014, p. 17). Marcadas tanto pelo holismo epistemológico e moral quanto pelo autoritarismo, as doutrinas antiliberais esmeravam-se na divinização do Estado, do líder e do partido. A identificação da democracia apenas com o liberalismo arquetípico o levaria a incluir até intelectuais de tendência social-democrata, como Hélio Jaguaribe, Guerreiro Ramos e Celso Furtado, no rol daqueles inclinados ao autoritarismo (LYNCH; CASSIMIRO, 2018).

\section{O "modelo nacionalista" de história das ideias políticas}

Aluno de Weber no Seminário de Munique, Carl Schmitt foi o principal responsável pela variante do paradigma de ciência política novecentista que tomava a nação representada pelo Estado como parâmetro da realidade política. Ele concordava com o diagnóstico weberiano relativo ao advento da modernidade como produto de um processo de secularização, que trouxera o capitalismo, a ciência e a burocratização. Concordava, igualmente, com a tese de que as ideologias eram resquícios secularizados de formas religiosas de intelecção do mundo. Entretanto, orientado por um modo católico ultramontano de pensar a política, Schmitt criticava aquela mesma modernidade como incompatível com a essência do político, cuja característica maior residia na capacidade que teria o soberano de decidir de maneira incontestável, sempre que estivessem em jogo valores transcendentes para a comunidade. Em Catolicismo romano e forma política (1923), a política era definida por Schmitt como luta: "O antagonismo está no universalmente humano" (SCHMITT, 1998, p. 44). Ao contrário de Weber, porém, não acreditava nem desejava que o antagonismo pudesse ser domesticado 
pelo racionalismo liberal. A dimensão teológica da ideologia estava associada aos "mitos" criadores da identidade nacional: "Nenhum sistema político pode sobreviver sequer a uma geração com simples técnica e afirmação do poder. Ao político pertence a ideia, pois não há nenhuma política sem autoridade e nenhuma autoridade sem um ethos de convicção" (SCHMITT, 1998, p. 31). Para Schmitt, o liberalismo não passava, também, de uma teologia protestante de índole romântica, abstrata, voltada para esvaziar a dimensão concreta e agonística da política, pela consagração do primado das relações econômicas, do pluralismo partidário, do federalismo, da separação de poderes e dos freios e contrapesos ${ }^{10}$. Mas eram tentativas baldadas. A "essência” da política não estava na rotina da legalidade, imanente, neutra, burocrática e impessoal, mas nas situações de exceção, que suspendiam aquela rotina e revelavam a "verdade do poder" em toda a sua inteireza. Como os milagres divinos e os golpes de Estado, a decretação da ditadura revelava, para Schmitt, o "verdadeiro soberano" e o caráter transcendente e existencial da política. Era o que ele explicava em Teologia política (1922):
A filosofia da vida concreta não pode subtrair-se à exceção e ao caso extremo, mas deve interessar-se por ele. Para ela, a exceção pode ser mais importante do que a regra, não por causa da ironia romântica do paradoxo, mas porque deve ser encarada com toda seriedade de uma visão mais profunda do que as generalizações dos repetidores medíocres. A exceção é mais interessante que o caso normal. O normal não prova

10 As relações entre Weber e Schmitt foram esmiuçadas por Kjell Engelbrekt: "Schmitt ativamente se apresentava na década de 1920 como herdeiro de Weber para obter credibilidade acadêmica. Em seu capítulo de 1923 [de O conceito do político] demonstra que desde o começo o jovem professor de direito se apropriou do trabalho de Weber, embora ao mesmo tempo solapasse a noção weberiana de liberalismo. Não seria um exagero dizer que depois ele seletivamente admitia ou ignorava os argumentos weberianos conforme a sua conveniência [...]. Havia várias coisas que ele não compreendia nos trabalhos de Weber, o que levou a muitas descaracterizações e, além disso, sua metodologia e filosofia da ciência diretamente contradiziam as próprias convicções de Weber. Durante a maior parte do tempo, Weber se apresentava acima de tudo como um cientista que orientava suas pesquisas a partir de problemas, e que ocasionalmente intervinha nos negócios públicos, enquanto Schmitt aparece como um acadêmico ideologicamente orientado, que recorria à história, à filosofia e à ciência para avançar as políticas públicas de sua preferência" (ENGELBREKT, 2009, p. 680). 
nada, a exceção prova tudo; ela não só confirma a regra, mas a própria regra vive da exceção. $\mathrm{Na}$ exceção, a força da vida real rompe a crosta de uma mecânica cristalizada da repetição (SCHMITT, 1996, p. 94).

Schmitt reconhecia que, em uma sociedade secularizada, não era possível reproduzir a admirável teologia política do Antigo Regime, cujas doutrinas do catolicismo, da razão de Estado e do absolutismo exprimiam com fidelidade a "realidade política". Por outro lado, na conjuntura de crise do liberalismo entre as duas guerras mundiais, ele acreditava na possibilidade de recuperar e atualizar aquela teologia para organizar uma verdadeira democracia de massas. A unidade e a homogeneidade do corpo político, outrora garantida pela Igreja e pelo príncipe, poderiam ser restauradas por um Estado totalitário, que rompesse com o anacrônico sistema parlamentar pluripartidário do liberalismo. Em Situação intelectual do sistema parlamentar atual (1923), Schmitt estabelecia uma distinção completa entre liberalismo e democracia: "A crença no sistema parlamentar, num government by discussion, pertence ao mundo intelectual do liberalismo. Não pertence à democracia. O liberalismo e a democracia devem ser separados" (SCHMITT, 1996, p. 10). Livre da ideologia burguesa, a democracia "verdadeira" se expressava por intermédio de uma ditadura cesarista, cujo líder fosse aclamado pelas multidões. Por isso, Schmitt considerava positivamente o fascismo de Mussolini como a expressão viva do "princípio da realidade política" na contemporaneidade (SCHMITT, 1996, p. 70). O "realismo político" passava pela afirmação da irredutível singularidade cultural de cada nação e na satisfação de suas necessidades existenciais, através da mobilização de mitos: "O mito mais forte está no sentimento nacional” (SCHMITT, 1996, p. 69). Daí porque o pacifismo era uma impossibilidade. Renovando o antigo "realismo" de Clausewitz e Treitschke, Schmitt defendia ser a guerra a expressão necessária da luta pela identidade e existência das nações, e que a noção cosmopolita de uma única humanidade não passava de "um ideal sem atividade política" (SCHMITT, 1992, p. 73). Representada pelo Estado, 
a nação se tornara a personagem central da "realidade", devendo ser apreendida como unidade particular, homogênea e indivisível, rompidas as neutralizações operadas pelas tentativas de autonomização da sociedade civil e do mercado pelos liberais. Era como ele explicava na sua Teoria da Constituição (1928):

Nação significa, frente ao conceito geral de povo, um povo individualizado pela consciência política de si mesmo. Diversos elementos podem cooperar para a unidade da Nação e a consciência dela: língua comum, comunidade de destinos históricos, tradições e recordações, metas e esperanças políticas comuns. [...]. Um Estado democrático que encontra seus pressupostos de sua democracia na homogeneidade de seus cidadãos, se corresponde com o chamado princípio da nacionalidade, segundo o qual uma Nação forma um Estado e um Estado encerra dentro de si uma Nação (SCHMITT, 1966, p. 268).

A história das ideias políticas desempenhava papel crucial na construção teórica de Schmitt. Em O conceito do político (1927), ele agrupava os clássicos em duas linhagens antagônicas. A primeira era composta por "idealistas" ou "normativistas". Eram aqui encaixados liberais como Locke, Montesquieu, Kant, Constant, Guizot, Mill, Tocqueville e Kelsen, que teriam trabalhado pela impossível despolitização da política pelo direito e pelo mercado a título de regenerar o homem. O liberalismo não passava de uma mera "ideologia" no sentido marxista da expressão, cujo fim era o de encobrir a realidade política para melhor defender o status quo. Socialistas como Marx e Kautsky também entravam na categoria de idealistas, embora em menor grau, por admitirem uma concepção agônica da política (trabalhadores versus burguesia), passível de superação por recurso a uma ditadura (a do proletariado). Já a segunda família intelectual de clássicos da política era integrada pelos "realistas" ou "decisionistas". A ela pertenciam teóricos da razão de Estado, como Maquiavel e Naudé; absolutistas, como Bodin, Hobbes e Bossuet; 
e reacionários, como De Maistre, De Bonald e Donoso Cortès. Porque acreditavam na natureza problemática e corrompida dos homens, eram esses os escritores que teriam efetivamente logrado discernir a "essência" da política:

Como eles [os realistas] não perdem jamais de vista o fato concreto, existencial, de um inimigo possível, estes pensadores políticos fazem frequentemente prova de uma espécie de realismo próprio a amedrontar os seres humanos ansiosos por segurança (SCHMITT, 1992, p. 110).

Se a capacidade de distinguir entre o amigo e o inimigo era a prova de uma "teoria política lúcida", para Schmitt, sua incapacidade ou recusa era sintomática de declínio político: "A realidade concreta da existência política não é comandada por hierarquias abstratas ou por um jogo de normas; ao contrário, não são nunca senão homens ou grupos concretos que dominam outros homens ou grupos concretos" (SCHMITT, 1992, p. 118). A partir daí ressurgiam as bases de uma história nacionalista das ideias políticas, à maneira daquela empreendida pelo jovem Meinecke, adaptada, porém, ao paradigma "científico" da ciência política novecentista, crítico da "metafísica" associada ao liberalismo.

Nos Estados Unidos, o novo "realismo" de fundo schmittiano teve de aclimatar-se a uma cultura política muito diversa da alemã, na qual era impossível romper completamente com o liberalismo. $\mathrm{O}$ expoente do conservadorismo norte-americano da década de 1930 era o teólogo Reinhold Niebuhr que, em Homem moral e sociedade imoral (1932), apontava os limites opostos pela natureza humana à pretensão dos progressistas de modificá-la. A objetividade moral seria impossível no âmbito coletivo, porque cada nação ou classe manifestava os próprios interesses por uma ideologia particular. Ele denunciava assim a vacuidade do idealismo de Kant e Dewey, para quem a educação poderia redimir o mundo: "O movimento liberal tanto religioso como secular parece ignorar a diferença básica entre moralidade dos indivíduos e a moralidade das coletividades, sejam 
raças, classes ou nações" (NIEBUHR, 1960, p. IX). Tendo em vista que a essência egoísta e conflitiva do homem não era passível de modificação pela razão ou pela moral, a ordem social precisaria sempre recorrer à pressão e à coerção (RICE, 1993). O "realismo" de Niebuhr foi transportado para a Ciência Política no começo da década seguinte por James Burnham, autor de Os maquiavelianos: defensores da liberdade (1943). O livro visava à apologia acadêmica dos chamados "elitistas": Mosca, Pareto, Michels e Sorel. Movido por uma "intensa e dominante paixão pela verdade", Maquiavel era apresentado como o fundador da linhagem do realismo político. Contrariando a filosofia normativa de seu tempo, ele teria lançado as bases de uma "verdadeira" ciência política, vista como pura "ciência do poder", objetiva e passível de validação pelo recurso a exemplos extraídos da história (BURNHAM, 1943, p. 53). Os elitistas italianos somente teriam seguido as pegadas do ilustre predecessor florentino, alcançando os mesmos excelentes resultados na modernidade. Na prática, a consagração da literatura "elitista” por Burnham servia para validar "cientificamente" as acusações de Niebuhr ao caráter supostamente ingênuo do liberalismo, confirmando a premissa de que a liberdade americana dependia de uma visão conservadora da política: "Através dos maquiavelianos, comecei a compreender de modo mais verdadeiro aquilo que eu já sentia havia muito: que apenas renunciando a todas as ideologias poderíamos começar a ver o mundo e o homem" (BURNHAM, 1943, p. VIII).

Foi a essa cultura política liberal que teve de se adaptar um antigo discípulo de Carl Schmitt: o jurista alemão Hans Morgenthau. Em seu processo de adaptação aos Estados Unidos, na condição de emigrado, ele verteu em odre novo o vinho velho trazido da Alemanha e entronizou Reinhold Niebuhr como sua nova referência em matéria de "realismo político" (JUTERSONKE, 2010, p. 30; PICHLER, 1998, p. 186). Em A política entre as nações (1948), Morgenthau afirmava que a política seria atravessada por um "conflito contínuo" de interesses contrariados, sendo vã a pretensão de erradicá-lo com vistas a uma ordem pacífica. O objetivo da ciência política não era orientar a ação para o bem, e sim evitar o 
mal maior, deixando de lado as abstrações para se guiar somente pelos "precedentes históricos" (MORGENTHAU, 2003, p. 4). A história da teoria política se resumiria a uma "crônica da contenda entre duas escolas doutrinárias que diferem fundamentalmente em suas concepções da natureza do homem, da sociedade e da política”. Aqui ele seguia em linhas gerais a tipologia de linhagens estabelecida por Schmitt em $O$ conceito do político. A primeira, utópica ou idealista, acreditava que "uma determinada ordem política, racional e moral, por ser derivada de princípios abstratos válidos universalmente, pode ser alcançada nas condições atuais e de pronto”. Ela pressuporia "a retidão inerente e a maleabilidade infinita da natureza humana" e atribuiria as deficiências, irracionalidade e imoralidade da política ao anacronismo das instituições, à má-fé de indivíduos ou à ignorância, males que poderiam ser corrigidos por diversos meios. A segunda escola - a realista, que era a dele - considerava "que o mundo, imperfeito como é do ponto de vista racional, resulta do encontro de forças inerentes à natureza humana" (MORGENTHAU, 2003, p. 3). Ao discutir a condição do intelectual e o dilema moral da política em $O$ declínio da política democrática (1962), depois das usuais homenagens a Niebuhr, Morgenthau recriminava a teoria política liberal por se ocupar unicamente do efêmero, ao invés de ater-se ao "sentido da realidade" do eterno: "Os dilemas moral da história são existenciais. Eles podem ser mitigados, mas não resolvidos" (MORGENTHAU, 1962, p. 14-15). Como Burnham antes dele, Morgenthau promovia uma conjunção de equivalências típicas do elitismo italiano ao longo de sua exposição teórica, que faziam do "realismo político" um sinônimo, tanto de "ciência política", quanto de "conservadorismo".

No Brasil, a polarização entre realismo e idealismo explodiu depois da Revolução de 1930. O grande inimigo era o idealismo cosmopolita dos liberais. Conforme esclarecia Almir de Andrade em Força, cultura e liberdade (1938), a literatura universalista que repudiava a ideia de pátria como prejudicial à paz e à fraternidade humana estava "mais próxima da metafísica do que da ciência", sendo "uma deplorável ilusão acerca da realidade humana" 
(ANDRADE, 1938, p. 30). Em O Estado autoritário e a realidade nacional (1938), Azevedo Amaral pretendia examinar o "conjunto da realidade nacional" a fim de demonstrar, por uma análise "científica", que a democracia não passava de uma "farsa caricata" fora dos países anglófonos (AMARAL, 1981, p. 43). Em O Estado Nacional: sua estrutura, seu conteúdo ideológico (1938), o principal divulgador da obra de Schmitt, Francisco Campos, sustentava que o caráter "realista" da nova Constituição só incomodava "os românticos e os ideólogos, que nunca ficam advertidos de que uma condição essencial da vida é nunca perder contato com a terra" (CAMPOS, 2001, p. 99). Em 1949, Oliveira Vianna retomaria sua famosa dicotomia em Instituições políticas brasileiras. Apresentando a ciência política como o conhecimento e a prática do direito público orientados pela sociologia, ele reprovava o "idealismo utópico" para fazer a apologia do nacionalismo político, entendido como uma "metodologia objetiva ou realista" destinada a "construir, senão uma ciência política, pelo menos uma pragmática política para o nosso Brasil" (VIANNA, 1974, p. 65). Miguel Reale e Manoel Gonçalves Ferreira Filho renovariam vinte anos depois o mesmo argumento, para estimular os generais a converterem a ditadura militar em uma "democracia limitada". Em A democracia possivel (1972), Ferreira Filho sublinhava que o "realismo político" exigia "imaginar instituições que facilitem a realização do ideal democrático, segundo as verdades da ciência política, desde que adaptadas ao momento e ao meio em que vive cada povo" (FERREIRA FILHO, 1972, p. 78-79). Em Da revolução à democracia (1977), Reale também argumentava que o "caráter objetivo" da ciência política aconselhava uma "orientação pragmática e realista quanto à solução do problema essencial da participação dos indivíduos nos benefícios da riqueza social". Ela deveria superar "os valores políticos do liberalismo clássico", sem se deixar "enredar pelos preconceitos e mitos inerentes ao marxismo" (REALE, 1977, p. 126).

Mas a proposta teórica de Oliveira Vianna também foi apropriada à esquerda, por intelectuais de inclinação social-democrata. Pioneiro na leitura de Weber e Mannheim no Brasil, Guerreiro 
Ramos afirmava na sua Introdução crítica à sociologia brasileira (1955) que, naquele momento histórico, o nacionalismo era um importante elemento de sustentação do esforço desenvolvimentista. A industrialização modernizaria a atrasada realidade brasileira, retirando-a de seu estado de alienação cultural em relação aos países cêntricos. Cada nação possuía uma ciência social que refletia seus problemas e tradições intelectuais no caminho da modernidade. Como o Brasil não deveria ser diferente, revisitar seu pensamento social era procedimento preliminar à constituição de uma ciência social a ele adaptada. Nesse quadro, parecia-lhe que a sociologia política de Oliveira Vianna, "na parte que diz respeito às nossas elites, é, certamente, o máximo de objetividade que, até agora, os estudos sociológicos atingiram, entre nós" (RAMOS, 1996, p. 79). O seu mapeamento preliminar do pensamento sociológico brasileiro detectava duas linhagens intelectuais principais. A primeira era por ele denominada de "enlatada" ou "consular", porque, importada do Atlântico Norte, ignorava que "os meios e os resultados do trabalho sociológico são condicionados por estruturas nacionais ou regionais. Afirma-se a eficácia imanente das transplantações”. A segunda corrente, "embora aproveitando a experiência acumulada do trabalho sociológico universal, está procurando servir-se dele como instrumento de autoconhecimento e desenvolvimento das estruturas nacionais e regionais" (RAMOS, 1996, p. 108) - a qual serviria de base a uma "sociologia autêntica", referida à realidade nacional. Ao se debruçar, depois, sobre o pensamento político brasileiro, ele identificaria a corrente "enlatada" com a ideologia conservadora, e a nacionalista, com a progressista. Tendo se referido por diferentes nomes à dicotomia idealistas vs. realistas ao longo dos anos, ele fixou-se afinal nas expressões hipercorretos e pragmático-críticos:

Hipercorreção é característica do posicionamento de intelectuais que, por força de sua identificação ambivalente com o elemento nacional, tendem a atribuir ideais e teorias importadas eficácia direta na configuração de comportamentos sociais, assim negligenciando os seus 
condicionamentos contextuais. O pragmatismo crítico, ao invés, caracteriza o posicionamento de intelectuais que, por força de sua identificação positiva com o elemento nacional e de sua sensibilidade às condições contextuais típicas do meio em que vivem, tendem mais a se servir das ideias e teorias importadas do que a admitir a sua exemplaridade abstrata (RAMOS, 1983, p. 533).

Oliveira Vianna e Guerreiro Ramos serviram de fontes imediatas para a interpretação do pensamento político brasileiro desenvolvida por Wanderley Guilherme dos Santos na virada de 1960-1970. A sua perspectiva de história do pensamento político se aproximava bastante de autores "realistas" como James Burnham, lido por ele durante sua pós-graduação nos Estados Unidos ${ }^{11}$. Wanderley chamava atenção para o problema do autoritarismo em uma sociedade que, percebendo-se atrasada e periférica, exigia um esforço prévio de construção nacional para o estabelecimento da democracia. No contexto periférico, a questão do nacionalismo e do papel do Estado transcendia em muito o papel conservador que lhe era atribuído nos países centrais ${ }^{12}$. Depois de destacar que a cultura política brasileira fora atravessada por conflitos descritos de

11 Responsável pela cadeira de Teoria Política no antigo IUPERJ (atual IESP-UERJ) nas décadas de 1970 e 1980, o programa criado por Wanderley Guilherme seguia a tese de Burnham de que com os elitistas começava o que se poderia chamar propriamente de ciência política moderna. Daí porque o seu estudo encerrava o módulo de Teoria Política I, dedicada aos "clássicos", e iniciava o de Teoria Política II, dedicada aos "modernos" (LYNCH, 2020, p. 40).

12 A inclusão de Guerreiro Ramos e Wanderley Guilherme no modelo nacionalista, a despeito de sua posição progressista à maneira de Weber, nada tem de contraditória. Em primeiro lugar, porque o ideário social-democrata não é incompatível com um nacionalismo moderado (MAYER, 1985, p. 37). Em segundo lugar, porque, no contexto periférico, a ideologia nacionalista perde frequentemente os contornos conservadores, como explica Raymond Aron:"As ideologias são suscetíveis de adquirir, em um quadro diferente, o significado aposta seu significado original. [...]. Nos países da América do Sul ou da Europa Oriental, se produziu mais de uma vez a mesma combinação de meios autoritários e objetivos socialmente progressistas. À imitação da Europa, foram criados parlamentos e introduzidos o direito de sufrágio, mas as massas eram iletradas, e as classes médias, débeis: as instituições liberais foram inevitavelmente monopolizadas pelos feudais ou pelos plutocratas, os grandes proprietários e seus aliados no Estado [... . Valores políticos e valores sociais e econômicos da esquerda, que marcaram as etapas sucessivas do desenvolvimento e estão em vias de conciliar-se finalmente na Europa, em outros lugares permanecem radicalmente dissociados" (ARON, 1955, p. 23-24). Esta última observação ajuda a explicar a designação de "autoritária instrumental", por Wanderley, de certa linhagem do pensamento brasileiro. 
forma dicotômica por seus intelectuais desde pelo menos o começo da República, ele afirmava em A Práxis Liberal no Brasil o predomínio de duas tradições intelectuais no seu pensamento político. A primeira era composta pelos liberais doutrinários, que acreditariam que "a reforma político-institucional no Brasil, como em qualquer lugar, seguir-se-ia naturalmente à formulação e execução de regras gerais adequadas". Acreditavam na eficácia de fórmulas universais independentemente das particularidades de cada país, incorrendo em uma "reificação institucional”. Eram, assim, "idealistas". Já os autoritários instrumentais, como o visconde de Uruguai, Alberto Torres e Oliveira Vianna, também desejavam, a exemplo dos liberais, que o Brasil se tornasse uma democracia liberal, mas acreditavam que sua sociedade era atrasada demais para atingir aquele fim por suas próprias pernas. Por isso, preferiam atribuir ao Estado o papel de "fixar as metas pelas quais a sociedade deveria lutar, porque a própria sociedade não seria capaz de fixá-las, tendo em vista a maximização do progresso nacional" (SANTOS, 1978, p. 106). Embora não aderisse abertamente a nenhuma das duas posições, tecendo críticas a ambas, a forma pejorativa como Wanderley denunciava o caráter alienado e elitista do liberalismo brasileiro e elogiava Oliveira Vianna e Guerreiro Ramos denunciavam suas preferências. Tanto mais que sua pesquisa se iniciara com a intenção de detectar as origens do pensamento do ISEB, instituto ao qual ele próprio pertencera. Para Wanderley, os autoritários instrumentais teriam conseguido pensar os dilemas da modernização periférica a partir de considerações concretas da sociedade brasileira (LYNCH, 2013). Foram, assim, "realistas".

\section{O modelo marxista de história das ideias políticas}

Conforme já referido, o socialismo científico de Marx e Engels apresentava-se na segunda metade do século XIX como o único sistema intelectual capaz de desvelar a "realidade" da exploração dos trabalhadores, oferecendo-lhes um instrumento cognitivo definitivo para combater a opressão. Os “idealismos" burguês e aristocrático (i.e., o liberalismo e o conservadorismo) eram considerados 
ideológicos porque negavam o fundamento material das relações sociais e incutiam nas classes dominadas uma falsa consciência que naturalizava a exploração, recorrendo a premissas falaciosas, tais como a da desigualdade natural da humanidade ou a da igualdade formal como a única possível. Cabia à revolução socialista romper com um passado intelectual dominado pela ideologia e pela falsa consciência da classe trabalhadora. A tradição dos mortos pesava como um pesadelo na cabeça dos vivos: "A revolução social do século XX não pode extrair a sua poesia do passado, mas apenas do futuro. Não pode começar consigo mesma antes de ter rejeitado todas as superstições em relação ao passado" (MARX, 1975, p. 57-58). Nesse contexto marxista de ruptura com os modos anteriores de pensamento, teológicos e metafísicos, não fazia o menor sentido uma história das ideias políticas pretensamente desinteressada. Ela deslocaria a atenção da infraestrutura para a superestrutura; adotaria um enfoque metafísico e não materialista; e daria protagonismo a indivíduos e não a classes. Para o socialismo científico, uma história intelectual só serviria para fazer a crítica do caráter mistificador das ideologias criadas para justificar a exploração dos trabalhadores, conforme os sucessivos modos de produção econômica. Era o que sugeria Plekhânov em $D a$ concepção materialista de história (1897):

A história das ideologias explica-se, em grande parte, pelo surgimento, a modificação e a destruição das associações de ideias sob a influência do surgimento, da modificação e da destruição de determinadas combinações de forças sociais (PLEKHÂNOV, 1956, p. 96).

Nesse quadro, uma história marxista das ideias, de caráter exemplar, só poderia ser uma história intelectual do próprio marxismo. Ela deveria ser redigida como uma narrativa de caráter teleológico que desembocasse no materialismo histórico de Marx e Engels, admitindo “precursores” como Babeuf, Owen e Proudhon 
e incluindo "sucessores" como Kautsky, Bernstein, Luxemburgo, Lenin, Trotsky, entre outros.

O modelo marxista mais profícuo para se pensar historicamente as relações entre realidade e intelecção foi elaborado por outro aluno de Weber: Gyorgy Lukács. Embora tenha depois renegado a sociologia compreensiva como um "idealismo subjetivo" (LICHTHEIM, 1970, p. 167), nem por isso ele deixou de com ela dialogar, elaborando uma solução marxista-historicista à questão da objetividade científico-social. O materialismo histórico não seria apenas um instrumento de conhecimento da realidade, mas também uma ação voltada para a modificar. Lukács resgatou a dialética hegeliana para criar uma síntese superadora dos impasses entre ciência e política. Em História e consciência de classe: estudos sobre a dialética marxista (1920), ele apresentava a realidade como resultado de uma prática (praxis) social cuja dinâmica resolvia naturalmente a antítese entre o pensamento (o ideal) e realidade (o real). A sua visão do fenômeno ideológico também era mais sofisticada do que a do marxismo vulgar: uma vez que todas as formas de pensamento seriam socialmente determinadas, cada classe social teria sua própria concepção de ciência. As ideologias eram as "consciências possíveis" da realidade de cada uma delas. Nem por isso elas estariam todas no mesmo plano qualitativo: algumas permitiriam compreender o real da forma mais efetiva do que as demais. Era o caso da consciência da classe trabalhadora que, uma vez liberada pelo marxismo dos condicionamentos ideológicos, lograria enxergar a realidade, na qualidade de classe universal: "Ciência e consciência coincidem para o proletariado porque ele é, ao mesmo tempo, o sujeito e o objeto do conhecimento: o conhecimento de si significa ao mesmo tempo o conhecimento correto de toda a sociedade" (LÖWY, 1987, p. 124). Daí a diferença entre Lukács e Mannheim: ao invés de um centro dinâmico ocupado por intelectuais desvinculados de sua condição de classe, o único "lugar social" de onde se poderia observar o mundo de modo menos ideologicamente comprometido seria aquele ocupado pela classe trabalhadora: 
A ciência burguesa - de maneira consciente ou inconsciente, ingênua ou sublimada - considera os fenômenos sociais sempre do ponto de vista do indivíduo. E o ponto de vista do indivíduo não pode levar a nenhuma totalidade [...]. A totalidade só pode ser determinada se o sujeito que a determina é ele mesmo uma totalidade; e se o sujeito deseja compreender a si mesmo, ele tem que pensar o objeto como totalidade. Somente as classes representam esse ponto de vista da totalidade como sujeito da sociedade moderna (LUKÁCS, 2003, p. 106-107).

A empreitada epistemológica lukacsiana foi continuada na França por Lucien Goldmann. Em Ciências humanas e filosofia (1952), Goldmann explicava o fenômeno ideológico como expressivo da tendência humana de modelar pensamentos e ações conforme os valores de seu próprio grupo social. Os valores classistas agiriam sobre a estrutura cognitiva dos pensadores, condicionando sua percepção dos fatos. Algumas classes sociais, porém, estariam mais próximas de conseguir ver a realidade do que as outras. Era o caso dos trabalhadores, cujo lugar social, instruído pelo marxismo e representado do Partido, permitia "o máximo de consciência possível". A intenção de Mannheim de atribuir aquele "lugar social" aos intelectuais era condenada por "transformar a verdade em privilégio de um certo número de diplomados e especialistas em sociologia" (GOLDMANN, 1976, p. 52). Na elaboração de uma história intelectual marxista, Goldmann sublinhava a necessidade de apreender a singularidade do acontecimento histórico em toda a sua totalidade concreta. A história deveria ser compreendida como uma sucessão de estruturas, entendidas como totalidades históricas transitórias expressivas de uma realidade em permanente reconstrução. Pensada à maneira de Hegel, uma história marxista da ideias deveria estudar os grandes intelectuais (os "gênios") que houvessem exprimido de modo sistemático e coerente ("total") as "consciências possíveis" de suas classes, desenvolvidas no interior de suas respectivas estruturas: 
O investigador sempre deve esforçar-se por encontrar a realidade total e concreta, ainda que não saiba poder alcançá-la a não ser de uma maneira parcial e limitada, e para isso esforçar-se por integrar no estudo dos fatos sociais a história das teorias a respeito desses fatos, assim por ligar o estudo dos fatos à sua localização histórica e à sua infraestrutura econômica e social (GOLDMANN, 1976, p. 28).

Não só a ideologia passava a designar antes um estilo social de pensamento do que uma mera ilusão, como permitia incorporar outros autores ao cânone de clássicos, além dos marxistas ${ }^{13}$. Nem por isso o historiador das ideias deveria deixar de expor criticamente as visões de mundo dos agentes, distinguindo os progressistas dos conservadores:

No domínio das ciências humanas, o desejo de compreender a realidade exige do investigador a coragem de romper com os preconceitos conscientes ou implícitos, de ter sempre presente que a ciência não se faz da perspectiva deste ou daquele particular, nem duma posição exterior e pretensamente objetiva, que supõe a eternidade das estruturas fundamentais da sociedade atual, mas da perspectiva da liberdade e da comunidade humana, a perspectiva do homem e da humanidade (GOLDMANN, 1976, p. 65).

A história marxista das ideias se difundiu no Brasil na década de 1950, com o propósito de denunciar o caráter alegadamente retrógrado e autoritário de sua sociedade, escamoteado pelas ideologias de classe. A "história das ideias" só podia existir como "história das ideologias". Foram exemplares desta perspectiva: O caráter nacional brasileiro: história de uma ideologia, de Dante Moreira Leite (1954);

13 "Enquanto obra conceitual, um sistema filosófico pode e deve ser julgado no plano do conceito e de sua adequação à verdade. Mas, enquanto expressão global de uma visão de mundo, filosofias 'falsas' podem ter certo valor graças à sua coerência interna e ao fato de representarem certa maneira de pensar e de sentir a vida e o universo, e por isso mesmo, um dos aspectos essenciais da realidade humana" (LÖWY; NAIR, 2008, p. 52). 
Ideologia do colonialismo: seus reflexos no pensamento brasileiro, de Nélson Werneck Sodré (1961) e Ideologia da Cultura Brasileira, de Carlos Guilherme Mota (1977). Este último aspirava a denunciar tudo o que se produzira "no sentido de mascarar, justificar, desviar ou diagnosticar os processos vividos" (MOTA, 1977, p. 50). A melhor interpretação marxista do pensamento político brasileiro, porém, seria formulada pelo cientista político Gildo Marçal Brandão em Linhagens do pensamento político brasileiro (2007). Influenciada pelo marxismo hegeliano de Lukács e Goldmann, Gildo compreendia aquelas linhagens como consciências historicamente determinadas, mas socialmente necessárias, ao menos em seu momento inicial de formulação (LYNCH; CHALOUB, 2021). As duas primeiras, elitistas ou antipopulares, teriam prevalecido até o início da democratização do país na década de 1950: a do "idealismo orgânico" e a do "idealismo constitucional". O idealismo orgânico corresponderia ao conservadorismo, que subordinava "todo dever-ser à estreita métrica do existente, reduz o necessário ao possível e este ao imediato, assume e transfigura a empiria" (BRANDÃO, 2007, p. 146). Dessa corrente faziam parte Uruguai, Alberto Torres, Oliveira Vianna e Azevedo Amaral. Já o "idealismo constitucional" acreditava que os problemas eram antes políticos do que sociais e que o segredo da democracia estava na construção institucional cumulativa. Dela fariam parte liberais como Tavares Bastos, Joaquim Nabuco, André Rebouças e Rui Barbosa. Com a massificação da política, teriam surgido duas outras linhagens, agora de caráter "progressista" e "antiaristocrático": o "radicalismo de classe média" (sugerido por Antonio Candido) e o "marxismo de matriz comunista". O primeiro seria um pensamento "socializante, quase sempre socialista, de matriz liberal, por vezes constitucionalista". Já o "materialismo histórico" ou "marxismo de matriz comunista" buscava "a unidade entre, digamos, a infra e a superestrutura na explicação do social” (BRANDÃO, 2007, p. 37-38).

Entretanto, a tentativa de Gildo Marçal de romper a estrutura dicotômica na categorização das linhagens intelectuais ficava prejudicada na medida em que ele admitia ser possível enquadrá-las 
em dois polos básicos, um "conservador" e o outro, "progressista". No primeiro, estariam as linhagens por ele denominadas genericamente como "idealismos opostos e complementares" (i.e., o "constitucional” e o "orgânico"), marcados pelo seu caráter "conservador" ou "aristocrático". No segundo polo, ficariam as outras duas linhagens (i.e., o "radicalismo de classe média" e o "marxismo de matriz comunista”), marcadas pelo caráter "progressista” e "antiaristocrático". Enquanto o primeiro polo era referido pejorativamente como produto de um "fetiche", o segundo elogiosamente considerado por sua abordagem "de esquerda", marcada pela "inter e pela transdisciplinaridade" e pela capacidade de fornecer um "conhecimento totalizante" da realidade (BRANDÃO, 2007, p.158-162). Ao fim e ao cabo, as linhagens políticas reapareciam agrupadas em dois polos básicos: o primeiro, negativo e "idealista", das ideologias conservadoras; e o segundo, positivo e "realista" das ideologias progressistas $^{14}$.

\section{Considerações finais}

Este artigo buscou, pela reconstituição das linhagens teóricas dos intérpretes do pensamento político brasileiro, compreender os motivos pelos quais eles organizaram as suas tradições intelectuais a partir de polos antagônicos ocupados por "idealistas" de um lado e "realistas" de outro, divergindo na caracterização de cada uma delas. Tal divergência refletiria uma disputa mais ampla dentro do campo da história do pensamento político, cada qual orientado por diferentes concepções da realidade e suas relações com a dimensão ética da vida social. Elas envolvem questões relativas às características da natureza humana (se boa ou má) e ao papel auxiliar do conhecimento histórico na sua compreensão (relativa

14 Caso a pesquisa visasse a oferecer um painel mais amplo de interpretações do pensamento político brasileiro, certamente mencionaria, no campo do marxismo, a influência exercida por Antonio Gramsci na ciência social de Luiz Werneck Vianna, Leandro Konder e Carlos Nelson Coutinho. Aplicada ao estudo dos autores do pensamento político brasileiro, essa perspectiva produziu uma bibliografia de grande interesse e qualidade, elaborada por acadêmicos como Marco Aurélio Nogueira, Maria Alice Rezende de Carvalho, Rubem Barboza Filho e Milton Lahuerta (LYNCH, 2016, p. 110-112). Este não foi, porém, o objetivo deste artigo. 
à perfectibilidade ou imutabilidade daquela natureza). A exigência generalizada por "realismo" decorreria de um paradigma "científico" de ciência política estabelecido na primeira metade do século XX, derivada do imperativo de substituir o vigente no século anterior, detratado como "idealista" por sua fundamentação metafísica. A adoção da oposição entre idealistas e realistas como critério de triagem teórica serviria a dois fins: primeiro, para classificar as diferentes concepções de mundo oferecidas pelos clássicos da política; segundo, para validá-las ou não do ponto de vista científico. Essa suposição de que haveria métodos científicos ideologicamente mais bem equipados para enxergar a realidade política foi recepcionada pela ciência política por Oliveira Vianna e influiu sobre a orientação das três principais interpretações do pensamento político nacional, elaboradas por Wanderley Guilherme dos Santos, Bolívar Lamounier e Gildo Marçal Brandão.

Foram as diferenças entre os três intérpretes na identificação das linhagens intelectuais que motivaram a pesquisa aqui apresentada. Os primeiros resultados revelaram que a dicotomia realismo versus idealismo na organização da história da teoria política era bastante anterior ao período entreguerras. Da mesma forma, o propalado "idealismo" do paradigma de ciência política vigente no século XIX, identificado com o liberalismo, não era alienado nem anticientífico, se entendido em seus próprios termos. "Idealistas" como Angell, Rui e Dewey não desconheciam a realidade: apenas não se conformavam com ela, desejando modificá-la a partir de críticas de ordem moral. Nem por isso a dicotomia idealismo vs. realismo deixaria de comportar a possibilidade de um meio termo, na forma de um idealismo prático ou realista como aquele sugerido por Tocqueville e Paul Janet. Tendo feito da ciência oitocentista um espantalho de "idealismo", todavia, o novo paradigma "científico" novecentista agitado inicialmente pelos socialistas, positivistas e elitistas levantou a bandeira do "realismo" metodológico. Ele encontraria a sua materialização mais bem-sucedida na ciência social de Max Weber, a partir da qual Mannheim desenvolveu uma proposta de ciência (descritiva) capaz de estudar, desde um "centro dinâmico", 
as diferentes formas ideológicas de conhecimento (normativos), em uma perspectiva pluralista, que não se limitava a opor "idealistas" e "realistas". Postos na defensiva, weberianos como Edward Carr e Raymond Aron rejeitaram o estilo normativo oitocentista para argumentar dentro do novo paradigma "realista". Isso não os impediu de defender as possibilidades éticas da política, aproximando-se da tradição moderada de liberais oitocentistas como Montesquieu e Tocqueville (ou Nabuco, no caso brasileiro), que advogavam uma espécie de "idealismo prático" em matéria política. É porque sua abordagem continuou comprometida com o liberalismo político, ainda que se tratasse de um liberalismo reformado, "realista", porque despido de sua antiga metafísica e organizador de uma democracia social regulada por instituições parlamentares e políticos responsáveis.

Nem por isso instaurou-se o sonhado reino da cientificidade em matéria de análise ou história das ideias políticas. Com o começo da Guerra Fria, muitos liberais de extração filosófica, como Kelsen, Popper e Hayek, adotaram uma postura mais doutrinária na defesa do liberalismo com o intuito de combater publicamente as "ideologias do totalitarismo". Mas o "novo" paradigma científico também serviu para que conservadores como Schmitt, Burnham e Morgenthau vendessem como objetividade científica o próprio "realismo político" por eles identificado com a nação. Por sua vez, a exigência de realidade por parte do socialismo foi expressa pela versão marxista de ciências sociais esboçada por Gyorgy Lukács e aprimorada por Goldmann. Ela reconhecia os condicionamentos sociais dos estilos de pensamento, privilegiando a consciência do proletariado como instância máxima de consciência possível contra as demais. $\mathrm{O}$ resultado foi o surgimento, na academia francesa, britânica e norte-americana, de três modelos de história intelectual, organizadas pela velha dicotomia "realismo" vs. "idealismo": o liberal; o nacionalista; e o marxista. Cada um deles adotava, como critério definidor do real, o valor que orientava sua visão de mundo - a liberdade contra o autoritarismo, a nação contra o cosmopolitismo e a igualdade contra a opressão de classe. Suas narrativas de 
história do pensamento privilegiavam a linhagem ideológica de seus autores, localizando-a no polo positivo que acessava o conhecimento adequado e/ou desejável da realidade, e aglutinando as demais no polo negativo, porque dela daria uma noção equivocada e/ou condenável. Esses três modelos de história intelectual se refletiram, com maiores ou menores adaptações, nas interpretações do nosso pensamento político, deixadas por Wanderley Guilherme, Bolívar Lamounier e Gildo Marçal. Não se trata aqui, obviamente, de diminuir o seu valor, porque suas interpretações foram muito além da mera identificação e mapeamento de tradições intelectuais. Ademais, as caracterizações das linhagens oferecem subsídios preciosos para compreendê-las, tanto do ângulo de seus defensores, quanto de seus detratores. Assim, enquanto autoritarismo instrumental (Wanderley), liberalismo (Bolívar) e marxismo de matriz comunista (Gildo) servem como descrições da autoimagem do nacionalismo, do liberalismo e do marxismo, respectivamente, as descrições do que sejam liberalismo doutrinário (Wanderley), autoritarismo (Bolívar) e idealismos orgânico e constitucional (Gildo) são valiosas por indicarem o modo crítico por que seus adversários as enxergam.

A existência de diferentes modelos de história intelectual é tão ineliminável quanto as ideologias que os inspiram. Esse fato deve desestimular o estudioso da aspiração ingênua de um dia conseguir reduzi-los a um único ou de impor o seu por meio de críticas ou argumentos científicos que, por melhores que sejam, são impotentes contra barreiras ideológicas. Mesmo assim não precisamos nos contentar, no campo estritamente acadêmico das ciências sociais, com um padrão de apresentação e explicação das tradições intelectuais em apenas dois polos antagônicos. Especialmente quando já está claro que categorias como idealismo e realismo não remetem a padrões científicos de análise, mas a estilos discursivos de argumentação concorrentes, cada qual reivindicando congruência com uma "realidade" definida a partir de valores e critérios distintos. Acima de tudo, não é razoável supor que, em um mundo de crescente pluralidade e complexidade, o campo político esteja sempre 
dividido em apenas duas tradições intelectuais: a nossa, verdadeira e boa, e a de nossos inimigos, falsa e má. Se os modelos de história intelectual são pelo menos três (o liberal, o nacionalista e o marxista), por aí já se infere a impropriedade de tratar das tradições como se fossem somente duas. A adoção de uma grade analítica dicotômica, alimentada por interesses práticos de intervenção no debate público, por mais defensável que seja do ponto de vista ético, pode produzir devastadores efeitos científicos. Ao reduzir artificialmente as hipóteses de pesquisa para predeterminar os resultados, ela esteriliza o potencial exploratório, inviabilizando uma agenda consistente de investigações. É verdade que, até certo ponto, a influência da ideologia sobre o método é inevitável, porque a neutralidade absoluta é uma impossibilidade para quem está enredado nas malhas do mundo social. Por outro lado, o reconhecimento da ilusão cientificista não autoriza o estudioso a abdicar do ideal de objetividade como horizonte normativo. Daí a necessidade de uma grade analítica mais complexa, capaz de contemplar os três gêneros ideológicos da modernidade - liberalismo, conservadorismo e socialismo -, bem como as suas diferentes espécies e nuances adquiridas na América Latina. Será possível, então, minimizar a incidência, sobre a pesquisa, da famosa "lei de Helvécios" descrita por Machado de Assis, nas suas Histórias sem data (1884):

Não sei se o leitor é da minha opinião; eu cuido que se pode avaliar um homem pelas suas simpatias históricas; tu serás mais ou menos da família dos personagens que amares deveras. Aplico assim aquela lei de Helvécios: "O grau de espírito que nos deleita dá a medida do grau do espírito que possuímos" (ASSIS, 2004, p.79).

\section{Referências}

AMARAL, Azevedo. O Estado autoritário e a realidade nacional.

Brasília: Câmara dos Deputados, 1981. (Publicado originalmente em 1938). 
ASI - Anais do Senado do Império do Brasil. 7 out 1843.

ANDRADE, Almir de. Força, cultura e liberdade: origens históricas e tendências atuais da evolução política do Brasil. Rio de Janeiro: Editora José Olympio, 1938.

ANGELL, Norman. A grande ilusão. Tradução de Sérgio Bath. Brasília: Editora UnB, 2002. (Publicado originalmente em 1910). ARON, Raymond. L'opium des intellectuels. Paris: Calmann-Lévy, 1955.

ARON, Raymond. Paz e guerra entre as nações. Prefácio de Antônio Paim. Tradução de Sérgio Bath. Brasília: Editora UnB, 2002. (Publicado originalmente em 1962).

ASSIS, Joaquim Maria Machado de Assis. Histórias sem data. Rio de Janeiro, Editora Globo, 2004. (Publicado originalmente em 1884). BARBOSA, Rui. Embaixada a Buenos Aires. Rio de Janeiro: Fundação Casa de Rui Barbosa, 1984.

BOBBIO, Norberto. Ensaio sobre ciência política na Itália. Tradução de Maria Celeste F. Faria Marcondes. Brasília: Editora UnB, 2002.

BRANDÃO, Gildo Marçal. Linhagens do pensamento político brasileiro. São Paulo: Hucitec, 2007.

BURNHAM, James. The machiavellians: defenders of freedom. Chicago: Gateway Edition, 1943.

CAMPOS, Francisco. O Estado nacional: sua estrutura, seu conteúdo ideológico. Brasília: Senado Federal, 2001. (Publicado originalmente em 1938).

CARR, Edward Hallett. Vinte anos de crise 1919-1939: uma introdução ao estudo das relações internacionais. Brasília: IRI, 2001. (Publicado originalmente em 1939).

CARVALHO, José Murilo de. Duas ou três coisas que eu sei sobre Wanderley. Insight Inteligência, Rio de Janeiro, ano XVIII, n. 71, p. 118-120, out./dez. 2015.

CASTIGLIONE, Dario; HAMPSHER-MONK, Iain (ed.). The history of political thought in national context. Cambridge: Cambridge University Press, 2001. 
DEWEY, John. Essays, reviews, miscellany, and "Impressions of Soviet Rússia”. In: DEWEY, John. The later works, 1925-1953. Carbondale: Southern Illinois University, 2008. v. 3: 1927-1928. DEWEY, John. Liberdade e cultura. Tradução de Eustáquio Duarte. Rio de Janeiro: Revista Branca, 1953.

ELIAESON, Sven. Constitutional cesarism: Weber's politics in their German context. In: TURNER, Stephen. The Cambridge companion to Weber. Cambridge: Cambridge University Press, 2000, p. 131-148.

ENGELBREKT, Kyell. What Carl Schmitt picked up in Weber's Seminar: a historical controversy revisited. European Legacy, London, v. 14, n. 6, p. 667-684, 2009.

FAORO, Raymundo. Existe um pensamento político brasileiro? Estudos Avançados, São Paulo, v. 1, n. 1, p. 9-58, 1987.

FERREIRA, Waldemar. História do direito constitucional brasileiro. São Paulo: Max Limonad, 1954.

FERREIRA FILHO, Manoel Gonçalves. A democracia possível. São Paulo: Saraiva, 1972.

FRANCO, Afonso Arinos de Melo. Curso de direito constitucional brasileiro. Rio de Janeiro: Forense, 1960. v. 2: Formação constitucional do Brasil.

GOLDMANN, Lucien. O que é Sociologia? Tradução de Lupe Cotrim Garaude e José Arthur Giannotti. Rio de Janeiro: Editora Difel, 1976.

GUIZOT, François. Histoire de la civilisation en Europe: depuis la chute de l'Empire romain jusqu’à la Révolution Française. 6. ed. Paris: Perrin et Cie, Libraires-Éditeurs, 1855.

HAYEK, Friedrich. O caminho da servidão. 5. ed. Tradução e revisão de Anna Maria Capovilla, José Ítalo Stelle e Liane de Morais Ribeiro. Rio de Janeiro: Instituto Liberal, 1990.

HAYES, Carlton J. H. A generation of materialism (1871-1900).

New York: Harper \& Row, 1941.

HEGEL, Georg Wilhelm Friedrich. Introdução à história da filosofia. Tradução de Artur Morão. Lisboa: Edições 79, 2006. 
HOLANDA, Cristina Buarque de. Teoria das elites. Rio de Janeiro: Zahar, 2011.

HUME, David. Ensaios morais, políticos e literários. In: BERKELEY, George; HUME, David. Tratado sobre os princípios do conhecimento humano; três diálogos entre Hilas e Filonous em oposição aos céticos e ateus; investigação sobre o entendimento humano; ensaios morais, políticos e literários. Traduções de Antônio Sérgio, Leonel Vallandro, João Paulo Gomes Monteiro e Armando Mora d'Oliveira. São Paulo: Editora Abril, 1984. (Coleção Os Pensadores).

JANET, Paul. Histoire de la science politique dans ses rapports avec la morale. 2. ed.. Paris: Librairie Philosophique de Ladrange, 1872. t. 1.

JASMIN, Marcelo Gantus; FERES JR., João. História dos conceitos: dois momentos de um encontro intelectual. In: JASMIN, Marcelo Gantus; FERES JR., João (org.). História dos conceitos: debates e perspectivas. Rio de Janeiro: Editora PUC-Rio; Edições Loyola; IUPERJ, 2006. p. 39-53.

JUTERSONKE, Oliver. Morgenthau, law and realism. Cambridge: Cambridge University Press, 2010.

KELSEN, Hans. A democracia. Tradução de Ivone Castilho Benedetti, Jefferson Luiz Camargo, Marcelo Brandão Cippola e Vera Barkow. São Paulo: Martins Fontes, 2000.

KUHN, Thomas. A estrutura das revoluções científicas. 5. ed. São Paulo: Editora Perspectiva, 1997.

LAMOUNIER, Bolívar. A representação política: a importância de certos formalismos. In: LAMOUNIER, Bolívar; WEFFORT, Francisco; BENEVIDES, Maria Vitória (org.). Direito, cidadania e participação. São Paulo: T.A. Queiroz Editor, 1981, p. 233-260 LAMOUNIER, Bolívar. Formação de um pensamento político autoritário na Primeira República: uma interpretação. In: FAUSTO, Boris (org.). História geral da civilização brasileira. Rio de Janeiro: Bertrand Brasil, 1974. p. 371-388. (t. III: O Brasil Republicano). 
LAMOUNIER, Bolívar. Tribunos, profetas e sacerdotes: intelectuais e ideologia no século XX. São Paulo: Companhia das Letras, 2014.

LICHTHEIM, George. As ideias de Lukács. Tradução de Jamir Martins. São Paulo: Cultrix, 1970.

LÖWY, Michael. As aventuras do barão de Münchhausen: marxismo e positivismo na sociologia do conhecimento. São Paulo, Busca Vida, 1987.

LÖWY, Michael; NAIR, Sami. Lucien Goldmann ou A dialética da totalidade. Tradução de Wanda Caldeira Brandt. São Paulo: Boitempo, 2008.

LUKÁCS, Georg. História e consciência de classe: estudo sobre a dialética marxista. Tradução de Rodnei Nascimento. São Paulo: Martins Fontes, 2003.

LYNCH, Christian Edward Cyril (2016). Cartografia do pensamento político brasileiro: conceito, história, abordagens. Rev. Bras. Ciênc. Polít., [Online], n. 19, p. 75-119, 2016.

LYNCH, Christian Edward Cyril. The institutionalization of Brazilian political thought in the social sciences: Wanderley Guilherme dos Santos' research revisited (1963-1978). Bras. Political Sci. Rev., [Online], v.7, n. 3, p. 36-60, 2013.

LYNCH, Christian Edward Cyril. Um pensador da democracia: a ciência política de Wanderley Guilherme dos Santos. DADOS Revista de Ciências Sociais, Rio de Janeiro, v. 63, n. 1, p. 75-119, 2020.

LYNCH, Christian Edward Cyril; CASSIMIRO, Paulo Henrique Paschoeto. Freedom through form: Bolívar Lamounier and the liberal interpretation of Brazilian political thought. Bras. Political Sci. Rev., [Online],, v.12, n. 2, p. 1-28, 2018.

LYNCH, Christian Edward Cyril; CHALOUB, Jorge Gomes. "Um projeto de pesquisa à esquerda”: Gildo Marçal Brandão e a interpretação marxista do pensamento político brasileiro. 2021. No prelo.

MANNHEIM, Karl. Ideologia e utopia. Tradução de César Guimarães. Rio de Janeiro: Zahar, 1972. 
MAQUIAVEL, Nicolau. O príncipe. Tradução de M. J. Goldwasser. São Paulo: Martins Fontes, 2001.

MARX, Karl. Textos filosóficos. Tradução de Maria Flor Marques Simões. Lisboa: Editorial Estampa, 1975.

MAYER, Jacob Peter. Max Weber e a política alemã: um estudo de sociologia política. Tradução de Ana Cândida Perez. Brasília: Editora UnB, 1985.

MAZUCATO, Thiago. Ideologia e utopia de Karl Mannheim: o autor e a obra. Prefácio de Vera Alves Cepeda. São Paulo: Ideias \& Letras, 2014.

MEINECKE, Friedrich. Cosmopolitanism and the national state. Translated by Robert B. Kimber. New Jersey: Princeton University Press, 1970.

MERQUIOR, José Guilherme. O liberalismo antigo e moderno. Tradução de Henrique de Araujo Mesquita. 3.. ed. São Paulo: É Realizações, 2014.

MORGENTHAU, Hans J. A política entre as nações: a luta pelo poder e pela paz. Traduzida por Oswaldo Biato da edição revista por Kenneth W. Thompson. Prefácio de Ronaldo Sardenberg. Brasília: Editora, UnB, 2003. (Publicado originalmente em 1948). MOSCA, Gaetano. História das doutrinas políticas desde a antiguidade. Tradução de Marco Aurélio de Moura Matos. 6. ed. Rio de Janeiro: Editora Guanabara, 1987.

MOTA, Carlos Guilherme. Ideologia da cultura brasileira. São Paulo: Ática, 1977.

NABUCO, Joaquim. Balmaceda. São Paulo: Editorial Progresso, 1949. (Publicado originalmente em 1895).

NABUCO, Joaquim. Escritos e discursos literários. Rio de Janeiro: Garnier, 1901.

NABUCO, Joaquim. Um estadista do império. Rio de Janeiro, Topbooks, 1997. (Publicado originalmente em 1897).

NAUDÉ, Gabriel. Considérations politiques sur les coups d'État. Paris: [S. n.], 1667.

NIEBUHR, Reinhold. Moral man and immoral society. A study in ethics and politics. New York: Charles Scribner's Sons, 1960. 
PARETO, Vilfredo. As elites e uso da força na sociedade. In: SOUZA, Amaury de (org.). Sociologia política. Rio de Janeiro: Zahar Editores, 1966, p. 51-70.

PARETO, Vilfredo. Sociologia. Organização de José Albertino Rodrigues. Tradução de Ruy C. Cunha. São Paulo: Ática, 1984. PICHLER, Hans-Karl. The godfathers of 'truth': Max Weber and Carl Schmitt in Morgenthau's theory of power politics. Review of International Studies, Cambridge, v. 24, n. 2, p. 185-200, Apr. 1998.

PLEKHÂNOV, G.. A concepção materialista de história \& o papel do indivíduo na história. Rio de Janeiro: Editorial Vitória Ltda, 1956.

RAMOS, Alberto Guerreiro. A crise do poder no Brasil (problemas da revolução nacional brasileira). Rio de Janeiro: Zahar Editores, 1961.

RAMOS, Alberto Guerreiro. A inteligência brasileira na década de 1930. à luz da perspectiva de 1980. In: CPDOC-FGV. A revolução de 30: seminário internacional. Brasília: Editora UnB, 1983. p. 527-556. (Coleção Temas Brasileiros, v. 54).

RAMOS, Alberto Guerreiro. Introdução crítica à sociologia brasileira. Rio de Janeiro: EDUFRJ, 1996. (Publicado originalmente em 1955).

REALE, Miguel. Da revolução à democracia. 2. ed. São Paulo: Editora Convívio, 1977.

RICE, Daniel F. Reinhold Niebuhr and John Dewey: an American Odissay. Albany: State University of New York Press, 1993.

ROTH, Günther; SCHLUCHTER, Wolfgang. Max Weber's vision of history: ethics and methods. Berkeley: University of California Press, 1984.

SANTOS, Wanderley Guilherme dos. A imaginação política brasileira: cinco ensaios de história intelectual. Prefácio e organização de Christian Edward Cyril Lynch. Rio de Janeiro: Revan, 2017.

SANTOS, Wanderley Guilherme dos. Ordem burguesa e liberalismo político. São Paulo: Duas Cidades, 1978. 
SCHMITT, Carl. Catolicismo romano e forma política. Prefácio, tradução e notas de Alexandre Franco de Sá. Lisboa: Hugin, 1998. SCHMITT, Carl. A crise da democracia parlamentar. Tradução de Inês Lohbauer. São Paulo: Scritta, 1996.

SCHMITT, Carl. La notion du politique \& théorie du partisan. Traduit de l'allemand par Marie-Louise Steinhauser. Préface de Julian Freund. Paris: Flammarion, 1992.

SCHMITT, Carl. Teoría de la Constitución. Traducción de Francisco Ayala. Mexico D.F.: Editora Nacional, 1966.

SOUSA, Paulino José Soares de. Visconde do Uruguai. Organização e introdução de José Murilo de Carvalho. São Paulo: Editora 34, 2002. SUÁREZ, Francisco. Defesa da fé católica. São Paulo: Editora Concreta, 2015.

TORRES, Alberto. Discurso de posse. Revista do Instituto Histórico e Geográfico Brasileiro, v. 74, n. 124, p. 546-601, 1911.

TREITSCHKE, Heinrich von. Selections from Treitschke's lectures on politics. Translated by Adam L. Gowans. New York: Frederick \& Stokes Company Publishers, 1914.

VIANNA, Francisco José de Oliveira. O idealismo na evolução política do Império e da República. São Paulo: Biblioteca d’o Estado de São Paulo, 1922.

VIANNA, Francisco José de Oliveira. Instituições políticas brasileiras. 3. ed. Rio de Janeiro: Record, 1974. v. II.

WEBER, Max. Ciência e política: duas vocações. Tradução de Leônidas Hegenberg e Octany Silveira da Mota. São Paulo: Cultrix, 2006. (Publicado originalmente em 1919).

WEBER, Max. Economia e sociedade: fundamentos da sociologia compreensiva. Tradução de Regis Barbosa e Karen Elsabe Barbosa. Revisão técnica de Gabriel Cohn. Brasília: Editora UnB, 1999. v. 2. WEBER, Max. Escritos políticos. Tradução de Regis Barbosa e Karen Barbosa. São Paulo: Martins Fontes, 2014.

\section{Resumo}

O artigo problematiza a tendência que têm os intérpretes do pensamento político brasileiro de organizar suas tradições intelectuais a partir de uma 
polarização entre idealistas, que veriam a realidade de forma distorcida, e realistas, que a veriam de forma adequada. Alega-se que a divergência entre os intérpretes, relativamente a quais fossem as linhagens "idealistas" e "realistas, reflete uma disputa entre diferentes concepções da realidade política e suas relações com a dimensão ética da vida social, presente há séculos na teoria política. A discórdia envolve questões relativas às características da natureza humana (se boa ou má) e ao papel auxiliar do conhecimento histórico na sua compreensão (relativa à perfectibilidade ou imutabilidade daquela natureza). A exigência generalizada por "realismo" decorreria da elaboração de um paradigma de ciência política estabelecido na primeira metade do século XX, derivada do imperativo de substituir aquele vigente no século anterior, detratado como"idealista". Esse novo paradigma, elaborado na Alemanha, teria sido adaptado à esquerda e à direita, originando três modelos de história intelectual - um liberal, outro nacionalista, e um terceiro marxista. Daí a tendência, no interior de cada um deles, de apresentar as linhagens a partir de uma estrutura dicotômica, que aglutina de um lado as linhagens ideologicamente "boas", e de outro, as "más". O artigo conclui destacando a necessidade de evitar as classificações dicotômicas, a fim dar conta de forma mais produtiva da complexidade ideológica da vida social.

Palavras-chave: Pensamento político brasileiro. Ideologias políticas. Teoria política. Ciência política. Idealismo e realismo.

\section{Abstract}

The article problematizes the tendency of Brazilian political thinkers to organize their intellectual traditions based on a polarization between idealists, who see reality in a distorted way, and realists, who see it properly. We argue that the divergence between these authors regarding which traditions are "idealistic" or "realist" reflects a dispute among different conceptions of political reality and their relations with the ethical dimension of social life, present for centuries in political theory. Disagreement involves questions about the characteristics of human nature (whether good or bad) and the auxiliary role of historical knowledge in understanding it (concerning the perfectibility or immutability of human nature). The widespread demand for "realism" would result from the elaboration of a political science paradigm established in the first half of the 20th century derived from the imperative to replace the perspective that was dominant in the previous century, now rejected as "idealistic". This new paradigm, 
developed in Germany, was adapted to the left and to the right, giving rise to three models of intellectual history - one liberal, another nationalist, and a third Marxist. Hence the tendency within each of these approaches to present a dichotomous structure of political traditions, bringing together, on the one hand, the ideologically "good" lines of thought, and on the other, the "bad" ones. The article concludes by highlighting the need to avoid dichotomous classifications to account more productively for the ideological complexity of social life.

Keywords: Brazilian political thought. Political ideologies. Political theory. Political science. Idealism and realism.

Recebido em 23 de abril de 2020

Aprovado em 27 de outubro de 2020 